\title{
Production of dissolved organic carbon by Arctic plankton communities: responses to elevated carbon dioxide and the availability of light and nutrients
}

Alex J. Poulton ${ }^{\mathrm{a},{ }^{*}}$, Chris J. Daniels ${ }^{\mathrm{a}, \mathrm{b}}$, Mario Esposito ${ }^{\mathrm{a}, \mathrm{b}}$, Matthew P. Humphreys ${ }^{\mathrm{b}}$, Elaine Mitchell ${ }^{\mathrm{c}}$, Mariana Ribas-Ribas ${ }^{\mathrm{b}, \mathrm{d}}$, Benjamin C. Russell ${ }^{\mathrm{b}}$, Mark C. Stinchcombe ${ }^{\mathrm{a}}$, Eithne Tynan ${ }^{\mathrm{b}}$, Sophie Richier $^{\mathrm{b}}$

a Ocean Biogeochemistry and Ecosystems, National Oceanography Centre, Waterfront Campus, Southampton, UK.

${ }^{\mathrm{b}}$ Ocean and Earth Sciences, University of Southampton, National Oceanography Centre Southampton, Southampton, UK.

${ }^{c}$ Scottish Association of Marine Sciences, Scottish Marine Institute, Oban, Argyll, UK.

${ }^{d}$ Carl von Ossietzky Universität Oldenburg, Institute for Chemistry and Biology of the Marine Environment, Wilhelmshaven, 26382, Germany.

* Corresponding Author. Tel: +44 2380597086.

E-mail address: Alex.Poulton@noc.ac.uk (Alex Poulton). 


\section{Abstract}

The extracellular release of dissolved organic carbon (DOC) by phytoplankton is a potentially important source of labile organic carbon for bacterioplankton in pelagic ecosystems. In the context of increasing seawater partial pressure of $\mathrm{CO}_{2}\left(p \mathrm{CO}_{2}\right)$, via the oceanic absorption of elevated atmospheric $\mathrm{CO}_{2}$ (ocean acidification), several previous studies have reported increases to the relative amount of carbon fixed into particulates, via primary production (PP), and dissolved phases (DOC). During the summer of 2012 we measured DOC production by phytoplankton communities in the Nordic seas of the Arctic Ocean (Greenland, Norwegian and Barents Sea) from both in situ sampling and during three bioassay experiments where $p \mathrm{CO}_{2}$ levels (targets $\sim 550 \mu$ atm, $\sim 750$ $\mu \mathrm{atm}, \sim 1000 \mu \mathrm{atm})$ were elevated relative to ambient conditions. Measurements of DOC production and PP came from $24 \mathrm{~h}$ incubations and therefore represent net DOC production rates, where an unknown portion of the DOC released has potentially been utilized by heterotrophic organisms. Production of DOC (net $p D O C$ ) by in situ communities varied from 0.09 to $0.64 \mathrm{mmol} C$ $\mathrm{m}^{-3} \mathrm{~d}^{-1}$ (average $0.25 \mathrm{mmol} \mathrm{C} \mathrm{m}^{-3} \mathrm{~d}^{-1}$ ), with comparative rates in two of the experimental bioassays (0.04 to $1.23 \mathrm{mmol} \mathrm{C} \mathrm{m}^{-3} \mathrm{~d}^{-1}$ ) and increasing dramatically in the third (up to $5.88 \mathrm{mmol} \mathrm{C} \mathrm{m}^{-3} \mathrm{~d}^{-1}$ ). When expressed as a fraction of total carbon fixation (i.e., PP plus $p D O C$ ), percentage extracellular release (PER) was $14 \%$ on average (range $2 \%$ to $46 \%$ ) for in situ measurements, with PER in the three bioassays having a very similar range (2\% to $50 \%)$. A marked increase in $p D O C$ (and PER) was only observed in one of the bioassays where nutrient levels (nitrate, silicic acid) dropped dramatically relative to starting (ambient) concentrations; no $\mathrm{pCO}_{2}$ treatment effect on pDOC (or PER) was evident across the three experiments. Examination of in situ net $p D O C$ (and PER) found significant correlations with decreasing silicic acid and increasing euphotic zone depth, indicating that nutrient and light availability were strong drivers of the partitioning of primary production between particulate and dissolved phases. Furthermore, the third bioassay experiment had relatively high levels of diatom biomass as well as a strong response to nitrate and silicic acid depletion, and we suggest that nutrient starved or light limited diatom communities may be strong producers of DOC in Arctic ecosystems.

\section{Keywords:}

Dissolved Organic Carbon; Arctic Ocean; Ocean Acidification; Phytoplankton; Bacteria; Diatoms. 


\section{Introduction}

The production of dissolved organic carbon $(p D O C)$ relates to the fraction of photosynthetically fixed carbon that is subsequently released to the extracellular medium in a dissolved form and can represent a substantial fraction (up to $50 \%$ ) of gross primary production (i.e. the sum of particulate and dissolved carbon fixation) (Marañón et al., 2005; Hansell, 2002; Hansell and Carlson, 2015). Production of DOC is an important source of organic carbon to sustain heterotrophic bacterial growth and respiration (Cole et al., 1982; Hansell, 2002; Hansell and Carlson, 2015).

Phytoplankton production of DOC can occur through passive diffusion of low molecular compounds through the cell membrane, especially from small cells due to their low surface area to volume ratio, and through active release under conditions of high light and nutrient stress (Kiørbe 1993; López-Sandoval et al., 2011). Microzooplankton sloppy feeding, excretion and egestion may also be important sources of DOC (Nagata, 2000; Marañón et al., 2005; Robinson, 2008), especially in low nutrient conditions which are dominated by small cells and where the percentage of extracellular release $(\mathrm{PER}=100 \times(p D O C / \mathrm{PP}+p D O C))$ may represent 20 to $40 \%$ of gross primary production (e.g., Karl et al., 1998; Teira et al., 2001, 2003; López-Sandoval et al., 2011).

Elevated $p \mathrm{DOC}$ (and PER) from cellular exudation under sub-optimal conditions for phytoplankton has been suggested to be a cellular mechanism to compensate for the uncoupling between high energy (light) and low nutrients (Marañón et al., 2005; López-Sandoval et al., 2011). However, pDOC can also result from a number of processes which are more related to community trophic interactions, such as sloppy feeding or viral lysis (Nagata, 2000), and hence it is important to consider how $p D O C$ is measured when examining the source of DOC (Teira et al., 2001). A common method for measuring $p \mathrm{DOC}$ is through the separation of particulate and dissolved carbon fixation, with dissolved production representing pDOC. Radiolabelling (carbon-14) or using stable isotopes (carbon-13) potentially represents more accurate determinations of $p \mathrm{DOC}$ than time-series measurements of bulk DOC. Rapid utilization of photosynthetically fixed carbon by heterotrophic bacteria can also mask short-term DOC dynamics (Cole et al., 1982; Engel et al., 2004, 2013) making the source and trophic interactions of DOC producers and consumers complex to interpret. Due to this rapid utilization of released DOC, long incubations (12-24 h) measuring DOC production are likely to represent net DOC production, after a portion of the DOC has been respired by bacterioplankton, rather than gross DOC production.

Increased $p \mathrm{DOC}$ has also been linked to elevated $p \mathrm{CO}_{2}$, where increased carbon availability leads to an increased proportion of gross primary production (PP) being released into the dissolved phase (Engel et al., 2013). Such elevated pDOC has been seen in several studies (e.g., Engel et al., 2013) using mesocosm and other experimental setups to manipulate the $p \mathrm{CO}_{2}$ and $\mathrm{pH}$ 
conditions of natural communities over timescales of days to weeks. However, such bioassays are often nutrient enriched during the experimental set up leading to increased DOC production during nutrient replete growth phases of the experiments (Czerny et al., 2013), although rapid utilization of freshly produced DOC by microbial elements of the community may again hide biogeochemical responses and relationships (Cole et al., 1982; Engel et al., 2004, 2013). Other studies have seen little or no response in $p D O C$ (or PER) in experimentally manipulated communities, which may be linked to differing community structures, trophic interactions and environmental conditions (Yoshimura et al., 2010, 2013; Engel et al., 2004; Maugendre et al., 2015).

Examining the response of pelagic ecosystems to increased $\mathrm{pCO}_{2}$ is a pressing concern in biological oceanography due to the phenomenon of Ocean Acidification (OA). The anthropogenic release of $\mathrm{CO}_{2}$ into the atmosphere through fossil fuel burning has led to $\mathrm{OA}$, whereby atmospheric $\mathrm{CO}_{2}$ penetrates into the ocean declining surface ocean $\mathrm{pH}$ and perturbing the carbonate system from pre-industrial conditions (Royal Society, 2005; Fabry et al., 2009; Tynan et al., this issue). The solubility of $\mathrm{CO}_{2}$ increases with decreasing water temperatures and hence polar waters in both hemispheres are expected to be amongst the first areas to experience dramatic changes in surface water pH (Royal Society, 2005; Fabry et al., 2009). The sensitivity of polar marine organisms and ecosystems to declining pH is currently unclear (Fabry et al., 2009), though several studies have focused on OA effects on pelagic biogeochemistry and food webs (e.g., the KOSMOS mesocosms in Kongsfjord, Svalbard, see Czerny et al., 2013; bioassays in the Bering Sea and subarctic Pacific, see Yoshimura et al., 2010, 2013).

As well as being susceptible to imminent changes in surface water carbon chemistry and $\mathrm{pH}$, the Arctic Ocean is also experiencing increased temperatures which are causing earlier and more severe melting of seasonal ice in many regions (Boé et al., 2009; Fabry et al., 2009). The Arctic basin is subjected to significant riverine runoff which supplies large amounts of DOC to the Arctic Ocean (>200 mmol C m${ }^{-3}$ ), while inflowing water from the Atlantic and Pacific Oceans have concentrations $\sim 50 \mathrm{mmol} \mathrm{C} \mathrm{m}^{-3}$ (Anderson, 2002). Whilst some of this DOC is refractory and not directly available for biological uptake, high PP over the continental shelves and in association with ice edge blooms are also potentially significant sources of labile DOC through the release from algal cells or via sloppy feeding by zooplankton or viral lysis (Nagata, 2000). Recent measurements of bacterial respiration have shown that they represent a large fraction of total community respiration, indicating that bacteria play a key role in Arctic biogeochemistry and the marine carbon cycle in high latitude waters (Garcia-Martin et al., 2014a, 2014b). In an increasingly ice-free Arctic Ocean, the supply and biological sinks for DOC are likely to undergo rapid changes and hence understanding DOC dynamics is important to studies concerned with marine ecosystems under future climate forcing. 
The high susceptibility of Arctic Ocean marine ecosystems and biogeochemistry to OA and strong changes in seasonal ice melt magnitude and timing (Boé et al., 2009; Fabry et al., 2009) made the Arctic Ocean a natural focus for the UK OA programme (Tynan et al., this issue). In this context, the present study examines the production of dissolved organic carbon ( $p D O C)$ in Arctic communities sampled during the summer of 2012 (Fig. 1), both in natural in situ settings and within a number $(n=3)$ of experimental bioassays (with methodology identical to Richier et al., 2014) designed to examine the sensitivity of Arctic plankton to variability in $\mathrm{pH}$ and $p \mathrm{CO}_{2}$. It should be noted that due to the $24 \mathrm{~h}$ incubations of samples to determine PP and $p D O C$, these represent net rather than gross values (i.e. they do include respiratory losses). The overall aim of this study was two-fold: firstly to examine pDOC by unperturbed plankton communities; and secondly to examine $p D O C$ in plankton communities exposed to elevated $\mathrm{pCO}_{2}(550-1000 \mu \mathrm{atm})$. In both instances, $p D O C$ is also examined in the context of environmental conditions and plankton community

\subsection{Water sampling}

Water samples were collected during June 2012 from 19 stations in the Atlantic sector of the Arctic Ocean (Fig. 1a) during cruise 271 of the RRS James Clark Ross (JR271). Stations sampled included (Table 1): the Iceland-Faroes Front (C019); several stations in the Greenland Sea (C020, C021, C060, C063); several stations near the Greenland Ice Shelf, either in the ice-edge (C029, $\mathrm{C040})$ or in the ice (C027, C030, C032, C033); Fram Strait (C042); several stations in the Barents Sea (C047, C052, C054); several stations in the Norwegian Sea (C045, C056, C058); and one to the north of Iceland (C065). The Greenland Sea had sea surface temperatures $<5^{\circ} \mathrm{C}$, while the Norwegian Sea stations had sea surface temperatures $>5^{\circ} \mathrm{C}$ (Table 1, Fig. 1b). Stations in the Barents Sea were identified as being above the continental shelf (Fig. 1a), although clearly C047 was cold-water influenced due to the low SST in the northern Barents Sea (Fig. 1b, Table 1).

Water samples were collected from the middle of the mixed layer (10-30 m) in $20 \mathrm{~L}$ Niskin bottles on a CTD rosette sampler. Water samples from Niskin bottles were drawn into sample bottles for measurements of primary production (PP), total and $>10 \mu \mathrm{m}$ chlorophyll-a $(\mathrm{Chl})$, bacterial production $(\mathrm{BP})$, bacterial biomass $\left(\mathrm{C}_{\text {bact }}\right)$, macronutrient (nitrate, $\mathrm{NOx}$; phosphate, $\mathrm{PO}_{4}$; silicic acid, dSi) concentrations, carbonate chemistry parameters (dissolved inorganic carbon, total alkalinity) and particulate silica $\left(\mathrm{bSiO}_{2}\right)$. 
Sea-surface temperatures and salinities were taken from the CTD, with mixed layer depths estimated from the vertical density profiles. Daily incidental irradiance $\left(\operatorname{Ed}_{[0+]}\right)$, for Photosynthetically Active Radiation (PAR), was integrated from dawn to dusk (mol photons $\mathrm{m}^{-2} \mathrm{~d}^{-1}$ ) from the RRS James Clark Ross $2 \pi$ PAR irradiance sensor (Skye Instruments, SKE 510). The vertical diffuse attenuation coefficient of PAR $\left(K_{d}\right)$ in the water-column was calculated from early morning CTD stations, with the depth of the euphotic zone $\left(Z_{\text {eup }}\right)$ calculated as the depth where 1 $\%$ surface irradiance penetrates, with an optical depth of 4.6 .

\subsection{Experimental bioassays}

For experimental bioassays, water was also collected from the middle of the mixed layer (10-30 m) in $10 \mathrm{~L}$ trace-metal free Niskin bottles on a Titanium CTD rosette sampler. Experimental water was then dispensed randomly into 72 individual $4.2 \mathrm{~L}$ Nalgene bottles with gas-tight septum and seawater $p \mathrm{CO}_{2}$ concentrations were modified following Richier et al. (2014). Briefly, the initial carbonate chemistry in the seawater was characterized (see Richier et al., 2014; see also Tarling et al., this issue) and subsequently manipulated in the incubation bottles using an equi-molar addition of strong acid $\left(\mathrm{HCl}, 1 \mathrm{~mol} \mathrm{~kg}^{-1}\right)$ and sodium bicarbonate $\left(\mathrm{NaHCO}_{3}{ }^{-}, 1 \mathrm{~mol} \mathrm{~kg}^{-1}\right)$ (Gattuso et al., 2010). In addition, three independent bottles were measured immediately after manipulation and checked for the accuracy of the method.

For each treatment (ambient, $550 \mu \mathrm{atm}, 750 \mu \mathrm{atm}$ and $1000 \mu \mathrm{atm}$ ) there were 18 replicate bottles for measurement of a wide range of chemical, biological and biogeochemical parameters (see Table 3 in Richier et al., 2014) and the measurements for this study came from 6 replicate $4.2 \mathrm{~L}$ bottles from each $\mathrm{pCO}_{2}$ treatment. The microbial communities in each bottle were incubated in a purpose built commercial refrigeration container, with each treatment bottle racked in such a way that no two replicate treatment bottles were incubated alongside one another. Irradiance $(100 \mu \mathrm{mol}$ photons $\mathrm{m}^{-2} \mathrm{~s}^{-1}$ ) was provided by daylight simulation LED panels (Powerpax, UK) over a $24 \mathrm{~h}$ light cycle, which approximated the ambient photoperiod. Temperature was maintained at the in situ values $\left( \pm 1^{\circ} \mathrm{C}\right)$ at the time of water collection by the refrigeration unit and light levels were checked with a $4 \pi$ scalar PAR irradiance sensor (Biophysical Instruments, QSL-2101). Bioassays were subsampled through sacrificial incubation bottles at two time points, the first after $48 \mathrm{~h}$ and the second after $96 \mathrm{~h}$. Water samples for PP, total and $>10 \mu \mathrm{m}$ Chl, BP, $\mathrm{C}_{\text {bact }}$, macronutrient concentrations, and particulate silica $\left(\mathrm{bSiO}_{2}\right)$ were taken from 3 replicate bottles per $\mathrm{pCO}_{2}$ treatment at both time points. Dissolved inorganic carbon and total alkalinity samples were taken from all experimental bottles at both times points. Samples for the determination of BP were only collected from the ambient and the most extreme $\mathrm{pCO}_{2}$ treatment (target $1000 \mu \mathrm{atm}$ ), and from 3 replicate bottles per $\mathrm{pCO}_{2}$ treatment at both times points. 


\subsection{Primary production and production of dissolved organic carbon}

207

208

209

210

211

212

213

214

215

216

217

218

219

220

221

222

223

224

225

226

227

228

229

230

231

232

233

234

235

236

237

238

239

240

241

For in situ measurements, water samples were collected in four $70 \mathrm{~mL}$ polycarbonate bottles and primary production was measured following Poulton et al. (2014). For the $\mathrm{pCO}_{2}$ bioassay experiments, individual treatment bottles were sub-sampled into $70 \mathrm{~mL}$ polycarbonate bottles from the $4.2 \mathrm{~L}$ treatment bottles for each replicate from each $p \mathrm{CO}_{2}$ treatment (i.e. 3 per $p \mathrm{CO}_{2}$ treatment). Carbon-14 labelled sodium bicarbonate (925-1739 kBq) was added to each bottle and then three of the bottles were incubated on deck or in the case of samples from the bioassays, samples were incubated in a purpose built constant temperature containerised laboratory (Richier et al., 2014). On deck incubations were carried out in incubators chilled with surface seawater and covered with light filters (Misty-blue and Grey, LEE UK) to replicate $55 \%$ of surface irradiance. When surface seawater temperatures were expected to drop sharply (e.g. on entering the Greenland Ice Sheet) in situ samples were incubated in the bioassay experimental container. The fourth sample for in situ measurements had $1 \mathrm{~mL}$ of borate buffered formaldehyde added and was incubated in the laboratory and used to measure abiotic uptake. In the case of the $\mathrm{pCO}_{2}$ bioassay experiments, an average value of the in situ abiotic uptake measurement $\left(0.01 \mathrm{mmol} \mathrm{C} \mathrm{m}^{-3} \mathrm{~d}^{-1}\right)$ was subtracted from all the PP rates measured. Production of dissolved organic carbon was measured following LópezSandoval et al. (2011) with the use of $0.2 \mu \mathrm{m}$ syringe end filtering units (Whatman GD/X Syringe filters with $0.2 \mu \mathrm{m}$ PTFE membrane) and gentle pressure. Five $\mathrm{mL}$ sub-samples were pipetted from each $70 \mathrm{~mL}$ incubation bottle into $10 \mathrm{~mL}$ syringes and gently filtered through a syringe end filtering unit. Fresh pipette tips, syringes and syringe-end filters were used for each sub-sample to avoid potential contamination.

Percentage Extracellular Release (PER) was calculated as:

$$
\text { Percentage Extracellular Release }(\mathrm{PER})=100 \times(p D O C /(p D O C+\mathrm{PP}))
$$

The average relative standard deviation (RSD = Standard deviation/Average $\times 100)$ was 16\% (1$56 \%$ ) for total PP, and 35\% (2-80\%) for pDOC. High RSD for PP was associated with the presence of the colonial haptophyte Phaeocystis at several stations (C029, C040) (Le Moigne et al., 2015).

\subsection{Chlorophyll, macronutrients, particulate silica and carbonate chemistry}

Total chlorophyll-a (Chl) was quantified according to Poulton et al. (2014), with water samples $(0.25 \mathrm{~L})$ filtered onto Whatman GF/F filters, extracted in $8 \mathrm{~mL} 90 \%$ acetone, and stored at $4^{\circ} \mathrm{C}$ for 18-20 h. Fluorescence was measured on a Turner Designs Trilogy fluorometer, calibrated with 
purified Chl (Sigma, UK) and drift in the fluorometer was monitored using a solid standard.

Chlorophyll in the $>10 \mu \mathrm{m}$ fraction was measured on a $10 \mu \mathrm{m}$ polycarbonate filter $(0.25 \mathrm{~L})$, with $\mathrm{Chl}$ in the $<10 \mu \mathrm{m}$ fraction calculated as the difference between total and the $>10 \mu \mathrm{m}$ fraction.

Surface macronutrient (nitrate+nitrite, NOx; phosphate, $\mathrm{PO}_{4}$; silicic acid, dSi) concentrations were determined using an auto-analyser following standard protocols (Grasshoff et al., 1983). Particulate biogenic silica $\left(\mathrm{bSiO}_{2}\right)$ measurements were made on $0.5 \mathrm{~L}$ seawater samples filtered onto $0.8 \mu \mathrm{m}$ polycarbonate filters (Nucleopore ${ }^{\mathrm{TM}}$ ), oven dried $\left(6-8 \mathrm{~h}, 50^{\circ} \mathrm{C}\right.$ ), and stored dry until samples were digested in $0.2 \mathrm{~mol}$ sodium hydroxide, neutralised with 0.1 mol hydrochloric acid, and then analysed using a ATI Unicam 8625 UV/VIS Spectrometer (Ragueneau and Treguer, 1994).

The methodology for dissolved inorganic carbon $\left(\mathrm{C}_{T}\right)$ and total alkalinity $\left(\mathrm{A}_{T}\right)$ sampling and analysis from CTD samples and experimental samples followed those outlined in Poulton et al. (2014) and Richier et al. (2014) (see also Tynan et al., this issue). Calcite saturation state $\left(\Omega_{\mathrm{C}}\right), \mathrm{pH}_{\mathrm{T}}$ and $p \mathrm{CO}_{2}$ for both CTD samples and the $96 \mathrm{~h}$ bioassay experiments were calculated from $\mathrm{C}_{T}, \mathrm{~A}_{T}$, nutrients, temperature, salinity and pressure data using the $\mathrm{CO}_{2} \mathrm{SYS}\left(\mathrm{CO}_{2}\right.$ system) program (v. 1.1; Van Heuven et al., 2011) using the carbonic acid dissociation constants of Lueker et al. (2000), the boric acid dissociation constant of Dickson et al. (1990a), the bisulphate ion acidity constant of Dickson et al. (1990b), and boron:chlorinity of Lee et al. (2010).

\subsection{Bacterial biomass and bacterial production}

Bacterial abundance was assessed with flow cytometry following Zubkov and Burkill (2006), with bacterial biomass estimated using a cellular carbon value of $1.6 \mathrm{fmol} \mathrm{C} \mathrm{cell}^{-1}$ (Lee and Fuhrman, 1987). Seawater samples $(1.6 \mathrm{~mL})$ were preserved with paraformaldehyde (PFA, $1 \%$ final concentration) in $2 \mathrm{~mL}$ polypropylene screw cap vials, refrigerated and analysed within 12 hours of collection. Samples were stained with SYBR Green I nucleic acid dye and analysed using a FACSort flow cytometer (BD, Oxford) with internal bead standards (Zubkov and Burkill, 2006).

Bacterial production (BP, mmol C m $\mathrm{m}^{-3} \mathrm{~d}^{-1}$ ) was estimated as the microbial uptake rate of Leucine using carbon-14 labelled leucine (Hartmann Analytic, Germany), added at a concentration of 20 $\mathrm{nM}$, in samples from different depths from each morning CTD. Subsamples of $1.6 \mathrm{~mL}$ from each sample were dispensed into $2 \mathrm{~mL}$ polypropylene screw cap vials containing carbon-14 leucine (Zubkov et al., 2000). Samples were fixed at each time point (20,40,60, and 80 mins) by the addition of $80 \mu \mathrm{L}$ of $20 \%$ PFA ( $1 \% \mathrm{v} / \mathrm{w}$ final concentration). Fixed samples were filtered onto 0.2 $\mu \mathrm{m}$ polycarbonate membrane filters soaked in non-labelled Leucine solution to reduce abiotic 
absorption of radiotracer onto the filters. Filtered samples were washed twice with $4 \mathrm{~mL}$ deionised water. Radioactivity of samples was measured as counts per minute (CPM) by liquid scintillation counting (Tri-Carb 3100, Perkin Elmer, UK). Microbial uptake of leucine was computed using specific activity of the Leucine radiotracer.

\section{Results}

\subsection{General oceanography}

During the June 2012 cruise, upper ocean $\left(10-30 \mathrm{~m}\right.$ ) temperatures ranged from $-1.6^{\circ} \mathrm{C}$ to $7.8^{\circ} \mathrm{C}$ (Table 1), with the lowest temperatures $\left(-1.5^{\circ} \mathrm{C}\right.$ to $\left.-1.6^{\circ} \mathrm{C}\right)$ associated with ice shelf conditions in the western Greenland Sea. Mixed layer salinities were also low $(<33.3)$ at the sites associated with the Greenland Ice Shelf (C030, C032, C033), whereas other sampling sites had salinities ranging from 34.6 to 35.2 (Table 1) and were much more indicative of open ocean conditions. The two iceedge stations $(\mathrm{C} 029, \mathrm{C} 040)$ have relatively warm temperatures $\left(3.1-3.5^{\circ} \mathrm{C}\right)$ and salinities more representative of open ocean sites $(\sim 35.0)$ than those found in the ice (Table 1$)$.

Euphotic zone depths $\left(Z_{\text {eup }}\right)$ ranged from shallow $(21 \mathrm{~m})$ to deep $(70 \mathrm{~m})$ across the sampling stations, with deep $Z_{\text {eup }}(>50 \mathrm{~m}$ ) mostly associated with ice conditions in the Greenland Sea (C030, C033) and in the Barents Sea (C047, C052, C054) (Table 1). The shallowest $Z_{\text {eup }}(<30 \mathrm{~m})$ were found at two ice-edge stations in the Greenland Sea and Fram Strait (C029, C040, C042). Upper ocean $\mathrm{pCO}_{2}$ concentrations were variable, ranging from 208 to $381 \mu$ atm across the sampling sites with no particular pattern related to the open ocean, ice-edge or ice-sheet sampling sites (Table 1). The highest surface $p \mathrm{CO}_{2}$ (381 $\mu$ atm) was at a Greenland Ice Shelf station (C032), whereas the lowest $p \mathrm{CO}_{2}$ values were associated with a nearby ice-edge station $(\mathrm{C} 029,209 \mu \mathrm{atm})$ and the Fram Strait station (C042, $208 \mu \mathrm{atm})$. In a similar way to surface $p \mathrm{CO}_{2}, \mathrm{pH}_{\mathrm{T}}$ also varied between sites (range 8.0 to 8.3 ), though it showed no clear pattern between oceanographic regions (Table 1).

Upper ocean nitrate (NOx) concentrations were generally $>6 \mu \mathrm{mol} \mathrm{N} \mathrm{kg}{ }^{-1}$ at most sites (Table 1). Three stations had NOx concentrations $<4 \mu \mathrm{mol} \mathrm{N} \mathrm{kg}{ }^{-1}$, two across Fram Strait (C029, C042) and one to the north of Iceland (C065), while two stations had NOx $<0.6 \mu \mathrm{mol} \mathrm{N} \mathrm{kg}{ }^{-1}$ (C019, C047). Phosphate concentrations (not shown) ranged from 0.2 to $0.8 \mu \mathrm{mol} \mathrm{P} \mathrm{kg}{ }^{-1}$ and showed a significant ( $p<0.001$ ) correlation with NOx (Pearson's product moment correlation, $r=0.94, n=21)$. The relative concentration of $\mathrm{NOx}$ to phosphate, represented here by $\mathrm{N}^{*}\left(=\mathrm{NOx}-16^{*} \mathrm{PO}_{4}\right.$; e.g. Moore et al., 2009), was low at all sites, as indicated by negative $\mathrm{N}^{*}$ values (from -5.8 to -1.2 ; Table 1 ). Hence, dissolved inorganic nutrient concentrations were always enriched in phosphate relative to 
NOx, with extremely low $\mathrm{N}^{*}$ values (less than -2 ) generally associated with ice influenced areas such as the Greenland Ice Shelf (C029 to C033), Fram Strait (C042) and the northern Barents Sea (C047) (Table 1).

Silicic acid ( $\mathrm{dSi}$ ) concentrations were generally $>2 \mu \mathrm{mol} \mathrm{Si} \mathrm{kg}{ }^{-1}$ at almost all sampling sites (Table 1), apart from the northern Barents Sea $\left(1.2 \mu \mathrm{mol} \mathrm{Si} \mathrm{kg}{ }^{-1}, \mathrm{C} 047\right)$. Highest dSi concentrations (>6 $\left.\mu \mathrm{mol} \mathrm{Si} \mathrm{kg}{ }^{-1}\right)$ were associated with the Greenland Ice Shelf (C020, C030, C032, C033). Relative to NOx concentrations, dSi concentrations $\left(\mathrm{Si}^{*}=\mathrm{dSi}-\mathrm{NOx}\right.$; e.g. Bibby and Moore, 2011) were often high at stations associated with ice influence, as indicated by positive $\mathrm{Si}^{*}$ values (Table 1). Conversely, oceanic stations in the Greenland Sea (C020,C021, C027, C060, C063), southern Barents Sea (C052, C054), and Norwegian Sea (C056, C058), all had negative Si* values indicating low dSi relative to NOx concentrations.

Incidental irradiance at the sea surface $\left(\mathrm{Ed}_{[0+]}\right)$ ranged from 19 to $67 \mathrm{~mol}$ photons $\mathrm{m}^{-2} \mathrm{~d}^{-1}$ during the June 2012 cruise (Table 1). High values (> 50 mol photons $\mathrm{m}^{-2} \mathrm{~d}^{-1}$ ) were experienced at an open ocean station in the Greenland Sea (C020) and at several of the stations associated with the Greenland Ice Shelf (C029, C030, C032). The lowest values ( $<25$ mol photons $\left.\mathrm{m}^{-2} \mathrm{~d}^{-1}\right)$ were experienced at stations associated with one of the ice-edge stations (C040), in the northern Norwegian Sea near Svalbard (C045) and in the southern Barents Sea (C052, C054). Most other sampling stations had values between 30 to 40 mol photons $\mathrm{m}^{-2} \mathrm{~d}^{-1}$ (Table 1).

\subsection{Total and microplankton chlorophyll a, bacterial biomass and bacterial production}

Total Chl ranged from 0.4 to $8.4 \mathrm{mg} \mathrm{m}^{-3}$ (average $2.1 \mathrm{mg} \mathrm{m}^{-3}$ ) in the mixed layer across the sampling sites (Table 2), being highest $\left(>6 \mathrm{mg} \mathrm{m}^{-3}\right.$ ) at the Iceland-Faroes front (C019) and at one of the ice-edge stations (C029). The in ice stations (C030, C032, C033) all had Chl values $<1.5 \mathrm{mg}$ $\mathrm{m}^{-3}$, along with oceanic stations in the Barents (C047, C052, C054), Greenland (C021, C060, C063) and Norwegian seas (CC058), as well as north of Iceland (C065). Microplankton (>10 $\mu \mathrm{m})$ $\mathrm{Chl}$ ranged from 0.02 to $3.1 \mathrm{mg} \mathrm{m}^{-3}$ (data not shown), which when expressed as a percentage of total Chl ranged from 2 to $50 \%$ (average 21\%) (Table 2). High microplankton contributions to Chl ( $>40 \%$ of total) occurred at only two sites, one in the Faroes-Iceland front (C019) and one in the southern Greenland Sea (C063), while low microplankton contributions (<10\%) occurred in the Fram Strait (C042), northern Norwegian Sea near Svalbard (C045) and in the Barents Sea (C047, C052, C054). Microplankton Chl ranged from 14-19\% at the in ice stations of the Greenland Ice Sheet (C030, C032, C033) and was $\sim 32-34 \%$ at the ice-edge stations (C029, C040) (Table 2). 
Bacterial biomass $\left(\mathrm{C}_{\text {bact }}\right)$, estimated from flow cytometry counts of bacterial abundance, ranged from 0.5 to $6.4 \mathrm{mmol} \mathrm{C} \mathrm{m}^{-3}$, with a cruise average of $2.2 \mathrm{mmol} \mathrm{C} \mathrm{m}^{-3}$ (Table 2). High $\mathrm{C}_{\text {bact }}(>3 \mathrm{mmol}$ $\mathrm{C} \mathrm{m}^{-3}$ ) was found at sites in the Iceland-Faroes front (C019), Norwegian Sea (C056, C058) and Greenland Sea (C063). Values of $\mathrm{C}_{\text {bact }}$ were lowest $\left(<1 \mathrm{mmol} \mathrm{C} \mathrm{m}^{-3}\right)$ in association with the in ice stations in the Greenland Ice Shelf (C030, C032, C033), Fram Strait (C042) and northern Barents Sea (C047), while the two ice-edge stations (C029, C040) had $C_{\text {bact }} \sim 2 \mathrm{mmol} \mathrm{C} \mathrm{m}^{-3}$. There was no statistically significant correlation (Pearson's product moment correlation, $p=0.77$ ) between total $\mathrm{Chl}$ and $\mathrm{C}_{\text {bact }}$, whereas there was a significant $(p<0.005)$ correlation between $\mathrm{C}_{\text {bact }}$ and microplankton $\mathrm{Chl}(r=0.635, \mathrm{n}=18)$.

Bacterial production (BP) ranged from 0.05 to $1.38 \mathrm{mmol} \mathrm{C} \mathrm{m}^{-3} \mathrm{~d}^{-1}$, with a cruise average of 0.28 mmol C m $\mathrm{m}^{-3} \mathrm{~d}^{-1}$ (Table 2). A lack of a significant relationship between BP and $\mathrm{C}_{\text {bact }}$ (Pearson's product moment correlation, $p=0.16$ ) resulted in BP showing a different distributional pattern than $\mathrm{C}_{\text {bact }}$ across the sampling sites. The highest BP $\left(>1 \mathrm{mmol} \mathrm{C} \mathrm{m}^{-3} \mathrm{~d}^{-1}\right)$ was measured in the FaroesIceland front (C019), whereas many of the sampling stations had BP rates $\sim 0.2$ to $0.4 \mathrm{mmol} \mathrm{C} \mathrm{m}^{-3}$ $\mathrm{d}^{-1}$ (Table 1). Low BP $\left(<0.2 \mathrm{mmol} \mathrm{C} \mathrm{m}^{-3} \mathrm{~d}^{-1}\right)$ occurred at the three in ice stations (C030, C032, C033), the northern Norwegian Sea (C045), southern Barents Sea (C052, C054) and north of Iceland (C065). In contrast to $\mathrm{C}_{\text {bact }}$, BP showed significant (Pearson's product moment correlation, $\mathrm{p}<0.05)$ correlations with both total $\mathrm{Chl}(\mathrm{r}=0.51, \mathrm{n}=21)$ and microplankton $\mathrm{Chl}(\mathrm{r}=0.59, \mathrm{n}=18)$.

\subsection{Primary production and production of dissolved organic carbon}

Upper ocean rates of primary production (PP) ranged from 0.4 to $5.2 \mathrm{mmol} \mathrm{C} \mathrm{m}^{-3} \mathrm{~d}^{-1}$ across the sampling sites (Fig. 2., Table 2). High rates of PP $\left(>3 \mathrm{mmol} \mathrm{C} \mathrm{m}^{-3} \mathrm{~d}^{-1}\right)$ were found at the IcelandFaroes front (C019), at the ice-edge of the Greenland Ice Shelf (C029, C040), Fram Strait (C042) and in the Norwegian Sea (C058). Rates of DOC production ( $p D O C$ ) ranged from 0.09 to 0.64 mmol C m${ }^{-3} \mathrm{~d}^{-1}$ (Fig. 2), with an average value of $0.26 \mathrm{mmol} \mathrm{C} \mathrm{m}^{-3} \mathrm{~d}^{-1}$ for the sampling sites (Table 2). High $p D O C\left(>0.4 \mathrm{mmol} \mathrm{C} \mathrm{m}^{-3} \mathrm{~d}^{-1}\right)$ occurred at stations in the Iceland-Faroes front (C019), southern Barents Sea (C054) and southern Greenland Sea (C063) (Fig. 2). Low pDOC (<0.1 mmol $\mathrm{C} \mathrm{m}^{-3} \mathrm{~d}^{-1}$ ) were only measured at two stations, one in the ice (C033) and one across Fram Strait (C042), whereas the majority of sampling sites had values between 0.1 and $0.3 \mathrm{mmol} \mathrm{C} \mathrm{m}^{-3} \mathrm{~d}^{-1}$ (Table 2). There were no statistically significant relationships between PP or total Chl and pDOC (Pearson's product moment correlation, $p=0.41$ and $p=0.73, n=19$, respectively). There was also no significant relationship between PP and $C_{\text {bact }}$ (Pearson's product moment correlation, $p=$ $0.36, n=19)$, though there was a significant $(p<0.05)$ relationship between PP and BP $(r=0.53, n$ $=19)$. 
When expressed as a percentage of total PP, Percentage Extracellular Release (PER) ranged from $2 \%$ to $46 \%$ (Fig. 2), with a cruise average of $15 \%$ (Table 2). The highest values $(>30 \%$ ) of PER were found at two sites in the Barents Sea (C047, C054) while the lower values $(<10 \%)$ were found at the ice-edge stations (C029, C040), Fram Strait (C042) and in the Norwegian Sea (C056, C058) (Fig. 2). Hence, PER increased in cases where $p D O C$ was higher than average and PP was roughly average (e.g., C054), and also when pDOC was higher than average and PP was lower than average (C047) (Table 2). There was also a significant $(p<0.05)$ inverse correlation between total $\mathrm{Chl}$ and PER (Pearson's product moment correlation, $r=-0.48, n=19$ ). No significant relationships were found between $p D O C$ or PER and BP (Pearson's product moment correlation, $p$ $=0.34$ and $p=0.55)$ or $C_{\text {bact }}(p=0.28$ and $p=0.52)$.

Potential relationships between $p D O C$ or PER and the hydrographic parameters described in Table 1 were also examined (Fig. 3). The only significant relationship $(p<0.003)$ for $p D O C$ was an inverse one with dSi concentration (Pearson's product moment correlation, $r=-0.64, p<0.003, n=$ 19), indicating that $p \mathrm{DOC}$ increased significantly with decreasing dSi (Fig. 3). For PER, a significant (Pearson's product moment correlation, $p<0.01$ ) inverse relationship was again found with $\mathrm{dSi}(\mathrm{r}=-0.55, \mathrm{n}=19)$, as well as a significant $(\mathrm{p}<0.001)$ positive relationship with euphotic zone depth $\left(Z_{\text {eup }}\right)$ (Fig. 3). Hence, for the mixed layer samples, absolute $p D O C$ increased with decreasing nutrient ( $\mathrm{dSi}$ ) availability, and when expressed relative to PP, PER increased with increasing euphotic zone depth and decreasing light availability. No significant relationships were observed with SST, absolute nitrate (NOx) or nitrate relative to phosphate $\left(\mathrm{N}^{*}\right), p \mathrm{CO}_{2}, \mathrm{pH}_{\mathrm{T}}$ or incidental irradiance $\left(\mathrm{Ed}_{[0+]}\right)$ (Fig. 3).

\section{3. $\quad \mathrm{pCO}_{2}$ bioassays: macronutrients, primary production and production of dissolved organic carbon}

Initial conditions for the three bioassay experiments are given in Table 3 whilst Figure 4 presents the time course of variables in the experiments. The three bioassay experiments were geographically dissimilar in that one (EB-02) was in the sub-polar Iceland Basin, whilst the other two were associated with the Greenland Ice Sheet, one at the ice edge (EB-03) and one in openwater within the ice (EB-04) (Fig. 1A). These geographical variations are clear in the initial starting conditions in terms of hydrographic conditions and initial nutrient concentrations, although the carbonate chemistry of the three $\left(\mathrm{pCO}_{2}, \mathrm{pH}_{\mathrm{T}}\right)$ was similar (Table 3). One-way Analysis of Variance (ANOVA) tests were used to examine across treatments at each time point (as in Richier et al., 2014). 
In the first bioassay experiment (EB-02) there was a general trend for both total Chl and microplankton $(>10 \mu \mathrm{m}) \mathrm{Chl}$ to increase, whilst NOx decreased from $\sim 5 \mu \mathrm{mol} \mathrm{N} \mathrm{kg}{ }^{-1}$ to $\sim 1 \mu \mathrm{mol} \mathrm{N}$ $\mathrm{kg}^{-1}$ (Fig. 4). Although NOx decreased by $\sim 4 \mu \mathrm{mol} \mathrm{N} \mathrm{kg}{ }^{-1}$ from the initial value, dSi concentrations and $\mathrm{bSiO}_{2}$ remained at similar levels throughout $\left(\sim 1.5 \mu \mathrm{mol} \mathrm{Si} \mathrm{kg}{ }^{-1}\right.$ and $\sim 0.5-0.6 \mu \mathrm{mol} \mathrm{Si} \mathrm{kg}^{-1}$, respectively). In terms of treatment effects, only total $\mathrm{Chl}$ showed any significant variability (Fig. 4, $\mathrm{p}<0.05)$, being around twice as high in the $1000 \mu$ atm treatment relative to the others at the midtime point of the experiment. However, this difference had disappeared by the end time-point. Initial measurements for pDOC (and PER) were not made in EB-02 (Fig. 5) so changes from the initiation of the experiment cannot be examined. In EB-02 bacterial production (BP) decreased over the course of the experiment, though showing no difference between treatments (Fig. 5), whereas $\mathrm{C}_{\text {bact }}$ increased slightly at the mid-time point and then appeared to return to values similar to initial conditions.

In EB-03, both total $\mathrm{Chl}$ and $>10 \mu \mathrm{m} \mathrm{Chl}$ showed strong increases during the time course of the experiment with total $\mathrm{Chl}$ increasing by $\sim 2 \mathrm{mg} \mathrm{m}^{-3}$ and $>10 \mu \mathrm{m} \mathrm{Chl} \mathrm{from}<0.5$ to almost $3 \mathrm{mg} \mathrm{m}^{-3}$ at the end of the experiment (Fig. 4). The sharp increase in $>10 \mu \mathrm{m} \mathrm{Chl} \mathrm{that} \mathrm{occurred} \mathrm{between} \mathrm{the}$ mid-point and end point in EB-03 resulted in $>10 \mu \mathrm{m} \mathrm{Chl} \mathrm{representing} \sim 80-90 \%$ of the total Chl by the end of the experiment. At the end of EB-03, total Chl in the $750 \mu$ atm was significantly higher (Fig. 4, p<0.05) than in the other treatments and the $1000 \mu$ atm had noticeably lower $>10 \mu \mathrm{m} \mathrm{Chl}$ than the other treatments. Initial concentrations of NOx were high in EB-03 compared with the other bioassays (Table 3 ) and NOx decreased by $\sim 3 \mu \mathrm{mol} \mathrm{N} \mathrm{kg}{ }^{-1}$. Particulate biogenic silica $\left(\mathrm{bSiO}_{2}\right)$ increased during this bioassay from $\sim 0.5 \mu \mathrm{mol} \mathrm{Si} \mathrm{kg}{ }^{-1}$ to $2 \mu \mathrm{mol} \mathrm{Si} \mathrm{kg}{ }^{-1}$ which compares reasonably well with the $2 \mu \mathrm{mol} \mathrm{Si} \mathrm{kg}{ }^{-1}$ drawdown observed, and also with the strong increase in $>10 \mu \mathrm{m} \mathrm{Chl} \mathrm{(Fig.} \mathrm{4).} \mathrm{No} \mathrm{treatment} \mathrm{effects} \mathrm{were} \mathrm{seen} \mathrm{in} \mathrm{terms} \mathrm{of} \mathrm{nutrients} \mathrm{or} \mathrm{bSiO}_{2}$ in $\mathrm{EB}^{-03}$ (Fig. 4). In the case of $p D O C$ in EB-03 there was a notable lack of change in almost all treatments apart from the ambient treatment where it increased (Fig. 5, p<0.05). This pattern was also seen in PER (Fig. 5, p<0.05), highlighting how PP did not change dramatically across the treatments and showed only a slight increase with time (Fig. 5). BP peaked at the mid-point, being similar at the initial and end point of the experiment, with the difference at the mid-point not being significantly different (Pairwise t-test, $p=0.167$ ) (Fig. 5). Bacterial carbon $\left(C_{\text {bact }}\right)$ decreased dramatically

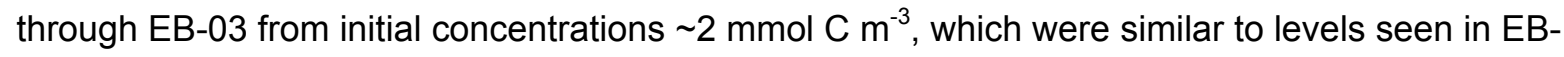
02 , to $<0.5 \mathrm{mmol} \mathrm{C} \mathrm{m}^{-3}$ at the end. Such a dramatic decrease in $\mathrm{C}_{\text {bact }}$ was not observed in any of the other experiments and represents a loss rate of $C_{\text {bact }}$ of $\sim 0.25 \mathrm{mmol} \mathrm{C} \mathrm{m}^{-3} \mathrm{~d}^{-1}$.

In EB-04, total Chl and $>10 \mu \mathrm{m} \mathrm{Chl} \mathrm{again} \mathrm{showed} \mathrm{an} \mathrm{increase} \mathrm{over} \mathrm{time,} \mathrm{with} \mathrm{an} \mathrm{increase} \mathrm{in} \mathrm{total}$ Chl of $\sim 2 \mathrm{mg} \mathrm{m}^{-3}$ and $\sim 4 \mathrm{mg} \mathrm{m}^{-3}$ across the experiment (Fig. 4). The high rise in $>10 \mu \mathrm{m} \mathrm{Chl} \mathrm{in} \mathrm{EB-}$ 04 resulted in this size fraction representing $80-90 \%$ of the total Chl by the end of the experiment. 
462

463

464

465

466

467

468

469

470

471

472

473

474

475

476

477

478

479

480

481

482

483

484

485

486

487

488

489

490

491

492

493

494

495

496

497

498

These increases in Chl were coupled with sharp declines in NOx (from 4 to $<1 \mu \mathrm{mol} \mathrm{N} \mathrm{kg}{ }^{-1}$ ) and dSi (from 12 to $4 \mu \mathrm{mol} \mathrm{N} \mathrm{kg}{ }^{-1}$ ) and sharp increases in $\mathrm{bSiO}_{2}$ (from 1.5 to $6-9 \mu \mathrm{mol} \mathrm{Si} \mathrm{kg}{ }^{-1}$ ) (Fig. 4). No significant treatment effects were evident in the nutrient drawdown, with NOx and dSi concentrations depleted to similar extents at the end of the experiment across treatments (Fig. 4). There was also a similar increase in $\mathrm{bSiO}_{2}$ across treatments, with the increase in $\mathrm{bSiO}_{2}(\sim 7.5$ $\left.\mu \mathrm{mol} \mathrm{Si} \mathrm{kg}{ }^{-1}\right)$ matching the drawdown of dSi $\left(\sim 8 \mu \mathrm{mol} \mathrm{Si} \mathrm{kg}{ }^{-1}\right)$ (Fig. 4). Both pDOC and PER increased dramatically at the end time point of the experiment relative to the mid-point, although there were no significant treatment effects. As in EB-03, BP in EB-04 peaked at the mid-time point and returned to rates similar to initial ones by the end of the experiment, and there was noticeably higher BP in the $1000 \mu$ atm relative to the ambient treatment (Fig. 4). In the case of $\mathrm{C}_{\text {bact }}$ in EB-04 there was an increase from initial concentrations of $\sim 0.7 \mathrm{mmol} \mathrm{C} \mathrm{m}^{-3}$ to $\sim 1.5$ to $>2 \mathrm{mmol} \mathrm{C} \mathrm{m}^{-3}$.

Overall, all three bioassay experiments (EB-02, EB-03, EB-04) showed increases in both total Chl and $>10 \mu \mathrm{m} \mathrm{Chl}$, drawdown of $\mathrm{NOx}$ and dSi and increases in $\mathrm{bSiO}_{2}$, although the rate of dSi drawdown and magnitude of $\mathrm{bSiO}_{2}$ increase was lowest where initial dSi concentrations were also lowest (EB-02) (Fig. 4, Table 3). Absolute pDOC (and PER) showed greater variability between bioassays, showing no change in one, an increase in the ambient in another and a sharp increase in the third (Fig. 5). Bacterial Production (BP) also varied over time and with $\mathrm{pCO}_{2}$ treatment across the three bioassay experiments, with a decrease in BP in the first bioassay and mid-point peaks in the second and third (Fig. 5). In terms of $\mathrm{C}_{\text {bact }}$, the three experiments had completely different patterns: one stayed roughly similar (EB-02), one decreased sharply (EB-03) and one increased (EB-04) (Fig. 5). Clearly slightly different processes occurred across the autotrophic community in the bioassays relative to the heterotrophic components of the community; however no clear treatment effect in terms of $\mathrm{pCO}_{2}$ was evident in any of the three bioassay experiments.

\section{Discussion}

\subsection{Carbon metabolism of Arctic plankton communities}

Although measurements of $p D O C$ have been made in the Arctic Ocean in the past (e.g., Gosselin et al., 1997), the use of absorbent glass fibre filters in many of these older studies means that there is uncertainty about the validity of these measurements (Karl et al., 1998). Across our sampling region, from the subpolar Iceland Basin to the Greenland Ice Sheet and polar Barents Sea (Fig. 1), we found a range of net $p D O C$ (0.09 to $0.64 \mathrm{mmol} \mathrm{C} \mathrm{m}^{-3} \mathrm{~d}^{-1}$; Table 2) similar to those reported in other marine studies: for example, Marañón et al. (2005) reported net pDOC ranging from 0.04 to $0.54 \mathrm{mmol} \mathrm{C} \mathrm{m}^{-3} \mathrm{~d}^{-1}$ in the central Celtic Sea in summer, while López-Sandoval et al. (2011) had rates of net $p D O C$ of $<0.01$ to $0.13 \mathrm{mmol} \mathrm{C} \mathrm{m}^{-3} \mathrm{~d}^{-1}$ in the Mediterranean Sea. 
In terms of PER, our range (2 to $46 \%$ ) and cruise average (15\%) also matches well with multiple

501

502

503

504

505

506

507

508

509

510

511

512

513

514

515

516

517

518

519

520

521

522

523

524

525

526

527

528

529

530

531

532

533

534

535

studies over many different regions: 5 to 33\% in the Southern Ocean (Morán et al., 2002a, 2002b), 6 to $37 \%$ in the Mediterranean Sea (Morán et al., 2002a; Lagaria et al., 2013), 7\% in the northeast Atlantic, and 4 to $42 \%$ in three Atlantic upwelling regions (Benguela, Mauritania and northwest Spain) and the oligotrophic North Atlantic (Teira et al., 2001). Furthermore, our PER values match with the historical study of Gosselin et al. (1997), who found PER to be $<20 \%$ in the Central Arctic Ocean (Chukichi Sea, Makarov and Nansen Basins).

From our sampling of the Nordic Seas of the Arctic Ocean, the highest rates of $p D O C(>0.3$ to 0.64

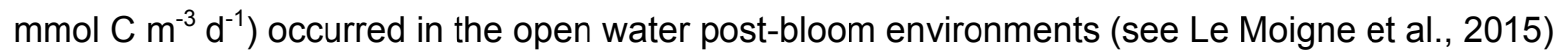
of the Barents and Norwegian Seas and from the Iceland-Faroes Front (Table 2). The ice edge stations (C029, C040) had low rates of pDOC and relatively high rates of PP leading to the lowest PER (<5\%) measured, with the Fram Strait station showing a similar pattern. The Greenland Ice sheet stations (C030, C032, C033) had moderate levels of $p \mathrm{DOC}$ and PER ranging from 10-18\%, which are not drastically different from many of the other stations sampled. Although the ice edge and ice stations had average levels of $p D O C$ and PER, it was noticeable that these stations also had low BP and $\mathrm{C}_{\text {bact }}$ (Table 2). Generally, stations in the Greenland Ice Shelf and at the ice edge did not show markedly different dynamics in terms of DOC production and only marginally lower levels of heterotrophic activity and biomass.

Spatial trends in pDOC (and PER) have been suggested to be linked to gradients in phytoplankton community structure and nutrient availability, so that the release of DOC increases as the community becomes nutrient impoverished and dominated by small cells (Teira et al., 2001, 2003; López-Sandoval et al., 2011). However, studies by Marañón et al. $(2004,2005)$ in vastly contrasting environments in terms of Chl concentrations, contribution of small cells to total biomass and production, and nutrient availability found very similar PER: $22 \%$ for the eutrophic Celtic Sea and $19 \%$ for the oligotrophic Ria de Vigo. In our case, in situ measurements showed no relationship between $p D O C$ and microplankton $\mathrm{Chl}$, although it was noticeable that in EB-04, as diatom biomass increased, $p \mathrm{DOC}$ also increased (see Section 4.3 for further discussion). Hence, there is little evidence from our observations of a strong influence of community composition on pDOC, although we only examine bulk expressions of community composition here (i.e. sizefractionated $\mathrm{Chl}$ and particulate silica concentration; Table 2).

The correlation between PP and pDOC was not statistically significant (Pearson product moment, $p=0.180$ ) and $p D O C$ was relatively invariant to variability in PP, although as PP decreased, PER increased. Other studies have observed significant relationships between PP and pDOC (e.g., 
Morán et al., 2002b; Marañón et al., 2005; López-Sandoval et al., 2011), while several studies have found, as we found, the opposite (e.g., Teira et al., 2001, 2003). Of these studies, the presence (or lack) of a relationship between pDOC and PP is not linked to incubation length, as significant relationships have been found from both short ( $<6 \mathrm{~h}$ ) incubations (Morán et al., 2002b) and long (24 h) incubations (Marañón et al., 2005; López-Sandoval et al., 2011). Teira et al. (2001) found a strong relationship between $p D O C$ and $\mathrm{PP}$ in upwelling nutrient-rich waters and no relationship in nutrient-poor subtropical waters. A positive relationship between PP and pDOC may indicate that extracellular release is a major source of DOC rather than trophic interactions (sloppy feeding, viral lysis), whereas a lack of relationship could indicate that extracellular release is less important and/or that there is significant consumption of the released DOC. Indeed, some studies (e.g., Teira et al., 2003) have used these relationships to determine whether the potential sources of DOC were from cellular exudation or trophic interactions. However, due to the potentially rapid utilization of DOC by heterotrophic components of the community and the complex trophic interactions in plankton communities, it would be premature to conclude the source mechanisms using only information on the relationship between PP and net $p D O C$.

Bacterial biomass $\left(\mathrm{C}_{\text {bact }}\right)$ in plankton communities sampled in the Greenland and Norwegian Seas ranged from 0.5 to $6.4 \mathrm{mmol} \mathrm{C} \mathrm{m}^{-3}$ in this study (Table 2), but did not correlate with total $\mathrm{Chl}(\mathrm{p}=$ 0.77 ) as observed by Cole et al. (1982). However, there was a statistically significant correlation with microplankton $(>10 \mu \mathrm{m}) \mathrm{Chl}$ (Pearson's product moment correlation, $r=0.635, p<0.005, n=$ 18). Such relationships between large phytoplankton (e.g., diatoms) and heterotrophic biomass potentially indicate stronger coupling of these elements of the ecosystem than seen in other marine environments, which are dominated by small cells.

Phytoplankton biomass $\left(\mathrm{C}_{\text {phyto }}\right)$, estimated from (total) $\mathrm{Chl}$ concentrations and a carbon to $\mathrm{Chl}$ ratio of 50 , ranged from 1.6 to $35 \mathrm{mmol} \mathrm{C} \mathrm{m}{ }^{-3}$. When expressed relative to $C_{\text {bact }}$, the ratio of $C_{\text {bact }}: C_{\text {phyto }}$ ranged from 0.1 to 1.0 , with a cruise average of 0.4 , indicating that heterotrophic biomass was almost half of that of autotrophic biomass and that there are likely to be strong linkages between the two. In some cases, higher ratios of $\mathrm{C}_{\text {bact }}: \mathrm{C}_{\text {phyto }}(>0.7)$ were found in open ocean environments of the Greenland and Norwegian Sea, with these sites likely to be post-bloom summer environments (Le Moigne et al., 2015) with active microbial loops and strong coupling between autotrophic and heterotrophic components of these ecosystems. This conclusion is also supported by a significant (Pearson's product moment correlation, $\mathrm{p}<0.01$ ) inverse relationship between $\mathrm{Si}^{*}$ and $\mathrm{C}_{\text {bact }}: \mathrm{C}_{\text {phyto }}(r=-0.58, n=19)$, indicating that with high NOx:dSi ratios (excess nitrate / depleted silicate) there is stronger coupling. 
The ratio of bacterial production (BP) to Primary Production (PP) ranged from 0.1 to 0.9 across the study area, although the cruise average was only 0.2 . This cruise average is similar to the average BP to PP ratio (0.3) found across a wide range of marine environments (del Giorgio and Cole, 1998). Only one site had a BP:PP ratio > 0.4 (C047, Barents Sea), and this site also had the lowest PP and nutrient concentrations sampled (Tables 1 and 2), indicating that this site represents an oligotrophic extreme. Variable BP to PP ratios are more indicative of differing degrees of coupling between the autotrophic and heterotrophic components of the ecosystems. The strength of linkage between such components of the ecosystem will critically depend on the characteristics of the dissolved organic matter (including DOC) released from the autotrophs and available for utilization by heterotrophic bacteria, as well as the requirements of the heterotrophs. For example, if the carbon demand for bacterial respiration and growth is met fully or partially by DOC release from phytoplankton.

To examine the degree to which bacterial carbon demand (BCD) was met by the release of DOC, we used the equation of Robinson (2008) to estimate bacterial respiration $\left(B R=3.69 \times \mathrm{BP}^{0.58}\right.$ ) and then BCD (= BP + BR) (see also Morán et al., 2002a, b; Teira et al., 2003; López-Sandoval et al. 2011). The average estimate of the pDOC contribution to BCD was $16 \%$ (range $4 \%$ to $43 \%$ ), with most stations $<20 \%$, apart from open ocean stations in the Greenland and Norwegian Seas, which were higher (Table 2). A lack of correlation between rates of DOC release and bacterial activity (BP) and a BCD in excess of $p D O C$ suggest the existence of additional organic carbon sources to support bacterial activity (Morán et al., 2002a,b; Teira et al., 2003). Additional DOC sources could include trophic process (zooplankton sloppy feeding, excretion and egestion, cell breakage through viral lysis; Nagata, 2000), as well as possible coastal sources of DOC (Moran et al., 2002a), or in the case of the communities in proximity to the ice sheets, exudation from ice-associated algae.

However, key to the estimation of BCD is knowledge of the bacterial growth efficiency (i.e. the relative amount of carbon invested in new cell production versus that used for respiration), which varies considerably ( $<5 \%$ to $60 \%$, del Giorgio and Cole, $1998 ; 7 \%$ to $69 \%$, García-Martín et al., $2014 \mathrm{a} ; 15 \%$ to $65 \%$, Wear et al., 2015), and our understanding of what factors regulate this variability is lacking (del Giorgio and Cole, 1998; Robinson, 2008). For example, studies have contradicted one another in their conclusions about temperature control of bacterial growth efficiency: Rivkin and Legendre (2001) found an inverse relationship, while García-Martín et al. (2014a) found no relationship. Factors determining bacterial growth efficiency may include such things as the metabolic potential and carbon content of the DOC, the taxonomic source and rate of DOC supply, the physiological condition or taxonomy of the bacterial cells, and the ecological or physiological pathways of DOC supply (del Giorgio and Cole, 1998; Fouilland et al., 2014; Wear et al., 2015). This uncertainty in the factors controlling BCD introduces significant uncertainties in 
609

610

611

612

613

614

615

616

617

618

619

620

621

622

623

624

625

626

627

628

629

630

631

632

633

634

635

636

637

638

639

640

641

642

643

644

645

estimates of $B C D$, and hence uncertainty in our conclusion that bacterial communities in the Arctic require alternative sources of $\mathrm{DOC}$ rather than the in situ plankton to meet their demands.

\subsection{Ocean Acidification and carbon dynamics in Arctic plankton communities}

Several previous studies have observed increased release of photosynthetically fixed carbon into the dissolved phase during exposure to elevated $\mathrm{CO}_{2}$ concentrations under experimental conditions (e.g., Engel, 2002; Czerny et al., 2013; Engel et al., 2013). Such results have been found in mesocosms in sub-polar and polar experiments (e.g., Czerny et al., 2013; Engel et al., 2013), as well as in smaller scale bioassays (e.g., Engel, 2002). Elevated $p \mathrm{CO} 2$ is believed to lead to 'over consumption' of carbon and a consequent increase in production of DOC and/or transparent exopolymer particles (TEP) (Engel, 2002). A number of studies have also found no change in $p D O C$ or PER with experimental increases in $p \mathrm{CO}_{2}$ (Yoshimura et al., 2010, 2013; Engel et al., 2014; MacGilchrist et al., 2014; Maugendre et al., 2015).

These previous studies examining the effects of increased $p \mathrm{CO}_{2}$ and perturbed carbonate chemistry conditions have tended to change $\mathrm{pCO}_{2}$ conditions over longer timescales (e.g., >4 d, Czerny et al., 2013) than used in this study ( $<2 \mathrm{~h})$. The $p \mathrm{CO}_{2}$ manipulation in this study was enforced on the ambient plankton communities within $<2 \mathrm{~h}$, which represents a much faster shift in carbonate chemistry than will be experienced with ocean acidification over the next century (see discussion in Richier et al., 2014). Hence, the small-scale bioassays used here tested community sensitivity to sharp changes in carbonate chemistry rather than acclimation or adaptation to OA conditions over weeks (mesocosms), decades or centuries (OA) (Poulton et al., 2014; Richier et al., 2014). Furthermore, previous studies on the effect of $p \mathrm{CO}_{2}$ changes on $\mathrm{DOC}$ release have often enriched their incubations with inorganic nutrients (e.g., Czerny et al., 2013; Engel et al., 2013,2014 ) or have retained the original nutrient conditions (e.g., Engel, 2002; Yoshimura et al., 2010, 2013; MacGilchrist et al., 2014; Maugendre et al., 2015). Studies which have observed increased $p D O C$ under elevated $\mathrm{CO}_{2}$ generally measure net $p \mathrm{DOC}$ (via changes in absolute DOC levels, e.g. Czerny et al., 2013, or over $24 \mathrm{~h}$ incubations, Engel et al., 2013), and hence these are not likely to be valid reasons for the differences between our observations and previous studies.

Given the abrupt changes in carbonate chemistry experienced by ambient plankton communities in our bioassay experiments, we still observed no overall effect of the different $p \mathrm{CO}_{2}$ treatments on DOC release (Figs. 4 and 5). During the time course of the three bioassay experiments in this study, strong increases in net pDOC and PER were only evident in one of the bioassays (EB-04) (Fig. 5) despite the strong increases in Chl (total and $>10 \mu \mathrm{m}$ ) and the drawdown of nutrients that occurred in all three bioassays (Fig. 4). Treatment effects, as shown by statistically significant 
differences between $\mathrm{pCO}_{2}$ levels, did occur but showed no clear trend across the three bioassays: for example, total Chl was significantly (one-way ANOVA, $p<0.05$ ) higher in the $1000 \mu$ atm at the mid-point $(48 \mathrm{~h})$ in the first bioassay, but not at the end, while significant $(p<0.05)$ differences in total $\mathrm{Chl}$ were limited to the $750 \mu \mathrm{atm}$ at the end time point (96 h) in the second bioassay (Fig. 4).

When relative changes in $p D O C$ and PER are plotted against changes in $p \mathrm{CO}_{2}\left(\Delta \mathrm{CO}_{2}\right.$; between treatment and initial levels) no clear trend of increasing treatment effect with $\Delta \mathrm{CO}_{2}$ is found at either time point in any of the bioassays (Fig. 6). However, when relative changes in pDOC and PER are plotted against changes in nutrients (NOx, dSi) between time points and initial concentrations, the third bioassay is clearly different to the other two bioassays with higher relative changes in $p D O C$ and PER at nutrient concentrations which are low relative to the initial (Fig. 7). Although the uptake of NOx was similar across the three bioassays $\left(\sim 4 \mu \mathrm{mol} \mathrm{N} \mathrm{kg}{ }^{-1}\right)$, the third bioassay stood out as the one in which NOx levels fell well below $1 \mu \mathrm{mol} \mathrm{N} \mathrm{kg}{ }^{-1}$ (Fig. 4). In the case of $\mathrm{dSi}$, the three bioassay experiments were very different (Fig. 4), although EB-04 again stood out as the one in which the largest decline occurred $\left(\sim 8 \mu \mathrm{mol} \mathrm{Si} \mathrm{kg}{ }^{-1}\right)$. Clearly, nutrient availability exerted an influence on the partitioning of production between the particulate and dissolved fractions in our bioassays in the Iceland Basin and Greenland Ice sheet, rather than $\mathrm{pCO}_{2}$ treatment.

Nutrient availability was also a strong control on pDOC and PER in the CTD samples, with statistically significant relationships with declining dSi concentrations (Fig. 3; Pearson's product moment correlation, $r=0.55, p<0.01, n=19)$. Increasing $Z_{\text {eup }}$ was also associated with increasing PER, though this is partly due to a strong correlation between $Z_{\text {eup }}$ and $P P(r=-0.81, p<0.001, n=$ 16). Marañón et al. (2005) found increased PER with increasing depth in the Celtic Sea, which was due to $p D O C$ being invariant with depth while PP showed a sharp decrease with depth (i.e. irradiance). This intricate relationship between PP and irradiance is likely to explain partially the relationship between PER and $Z_{\text {eup }}$ found in this study. Elevated $p D O C$ in the third bioassay (EB04) could also be related to reduced light availability as the strong increase in biomass occurring in this bioassay could have resulted in self-shading of the phytoplankton community.

Within the bioassay experiments, BCD showed the same trends as BP across the time points, while the proportion of $\mathrm{BCD}$ that $p \mathrm{DOC}$ potentially supplied varied greatly with no obvious $p \mathrm{CO}_{2}$ treatment effect or with nutrient availability (Table 4). In contrast to the in situ measurements, several of the time points in the bioassays had $p D O C$ rates that was in excess of BCD (i.e. $>100 \%$ ). This occurred at both $p \mathrm{CO}_{2}$ levels (ambient and $1000 \mu \mathrm{atm}$ ), but was more often associated with the end time point of the bioassay, while the highest ratios of $p \mathrm{DOC}: \mathrm{BCD}(>500 \%)$ occurred in the last bioassay (EB-04) when nutrient levels (NOx, dSi) were depleted to $\sim 0.1 \mu \mathrm{mol}$ 
683

684

685

686

687

688

689

690

691

692

693

694

695

696

697

698

699

700

701

702

703

704

705

706

707

708

709

710

711

712

713

714

715

716

717

718

719

$\mathrm{N} \mathrm{kg}^{-1}$ or below (Table 4, Fig. 4). Such high ratios of $p D O C$ to BCD imply that the phytoplankton community was producing more DOC than the bacterial community could utilize, partly due to the strong decreases seen in BP in all three bioassays at the end time point (Fig. 5). Bacterial biomass only decreased in the second bioassay (EB-03), whereas it remained stable (and high) in EB-02 and increased to similar levels $\left(\sim 2 \mathrm{mmol} \mathrm{C} \mathrm{m}^{-3}\right)$ as EB-02 in EB-04 (Fig. 5). Decreasing BP with little or no change in $\mathrm{C}_{\text {bact }}$ potentially indicates that the released $\mathrm{DOC}$ was being respired and our estimates of bacterial growth efficiency were inaccurate in these cases. It is also possible that the released DOC under conditions of nutrient starvation or rapid algal growth was markedly different in its characteristics (e.g., carbon to mineral stoichiometry; Wear et al., 2015), and caused higher respiration of DOC than that used for new cell growth.

Of the other parameters measured in the three bioassay experiments (e.g. $\mathrm{Chl}_{1} \mathrm{bSiO}_{2}, \mathrm{C}_{\text {bact }}$; Figs. 4 and 5), none showed a clear and repeatable treatment effect. However, similar temporal trends were observed in the three bioassays; for example, there was dSi drawdown in all three bioassays, and comparable increases in $\mathrm{bSiO}_{2}$ also occurred, though the magnitude in each was different (Fig. 4). In a very similar manner to dSi drawdown and $\mathrm{bSiO}_{2}$ production, microplankton Chl also increased across the three bioassays indicating an increasing dominance of large phytoplankton (e.g., diatoms) towards the end of the bioassays.

\subsection{Is there a role for diatoms as important DOC producers in the Arctic Ocean?}

Linkages between decreasing dSi availability and increased DOC production from both the in situ measurements (Fig. 3) and $p \mathrm{CO}_{2}$ manipulated bioassays (Figs. 4-7) may indicate that diatoms had a strong role in DOC production in our study. In contrast to the other bioassay experiments, DOC production was high in the EB-04 bioassay at low relative nutrient concentrations compared to initial concentrations (Fig. 7) rather than at increased $\mathrm{pCO}_{2}$ levels (Fig. 6). The mass balance between dSi drawdown and production of $\mathrm{bSiO}_{2}$ observed in the EB-03 and EB-04 bioassays (across all treatments), as well as the increasing dominance of the $>10 \mu \mathrm{m}$ fraction in terms of Chl (Fig. 4) and primary production (not shown), imply that diatoms became an increasingly dominant component of the autotrophic community in the last two bioassays.

Simple estimates of diatom carbon, through conversion of $\mathrm{bSiO}_{2}$ using a carbon to silicate ratio of 0.13 (Brzezinski, 1985), gives values of diatom carbon ranging from 0.1 to $28.6 \mathrm{mmol} \mathrm{C} \mathrm{m}^{-3}$

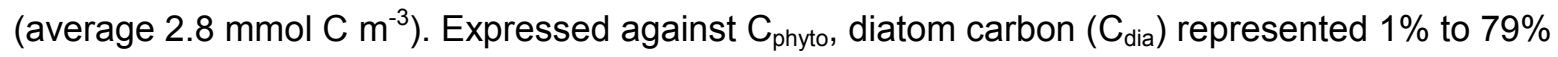
(average 35\%) across the Nordic Seas. (Note that this ignores two values $>100 \%$ from the Norwegian Sea (C058) and north of Iceland (C065), which are indicative that either the assumed carbon to $\mathrm{Chl}$ and/or carbon to silica ratio are incorrect for these stations.) In the case of the 
bioassays, estimates of $\mathrm{C}_{\text {dia }}$ give values ranging from 0.7 to $6.6 \mathrm{mmol} \mathrm{C} \mathrm{m}$ and 4.3 to $31.2 \mathrm{mmol}$ $\mathrm{C} \mathrm{m}^{-3}$ in EB-03 and EB-04 respectively, which equate to $9 \%$ to $69 \%$ and $38 \%$ to $>100 \%$, respectively, of estimated $\mathrm{C}_{\text {phyto }}$. Hence, diatoms represented a major component of the phytoplankton biomass, and potentially carbon fixation, across the Nordic Seas, implying an importance in DOC production as well as being recognised as having a major role in export of material during summer 2012 (see Le Moigne et al., 2015).

Diatom blooms are potentially large sources of DOC, with rapid DOC release following bloom peak as nutrients (NOx, dSi) are depleted and light availability changes, with selective use of this newly produced DOC by ambient bacteria communities (Norrman et al., 1995; Fouilland et al., 2014). In contrast, Wetz and Wheeler (2007) found high DOC release rates during exponential growth rather than when nutrients were depleted in batch cultures of various coastal diatom species. Also, a study by Fouilland et al. (2014) found significant DOC production from diatom communities and a closer coupling between bacteria and phytoplankton DOC exudation when there was high nutrient availability and low grazing, and small diatoms and autotrophic flagellates dominated the community. Observations in the Santa Barbara Channel (California) by Wear et al. (2015) during seasonal dSi depletion found that DOC concentrations (refractory and labile) both increased, and also that the bacterial growth efficiency increased during the latter stages of the bloom as the characteristics of the dissolved organic matter being released by the plankton community changed. Hence, diatoms and diatom-produced DOC can have a strong influence on DOC dynamics, including the degree of coupling between autotrophic and heterotrophic components of the carbon cycle. Our study therefore indicates a potentially important role of (dSi-starved or light-limited) diatoms in DOC production in the Nordic Seas of the Arctic Ocean.

\section{Conclusions}

There is a general consensus (e.g., Morán et al., 2002a; Teira et al., 2001, 2003) that the relative importance of $p D O C$ increases under strong nutrient limitation, and both our in situ and bioassay experiments provide support to this paradigm. The weak coupling between $p D O C$ and $B C D$ found in this study, and others (e.g. Morán et al., 2002a, b; López-Sandoval et al., 2011), potentially indicates weak coupling between phytoplankton exudation and bacterial metabolism. This weak coupling implies that in the Nordic Seas other DOC sources (e.g., coastal sources) are required to support bacterial respiratory requirements, which has also been concluded from coastal sites in the Antarctic (Morán et al., 2002a). However, we also note the variability in bacterial growth efficiency, which influences whether DOC supplied to bacteria is respired or used to make new cells, and the current uncertainty in the dominant factors which cause this variability. 
757

758

759

760

761

762

763

764

765

766

767

768

769

770

771

772

773

774

775

776

777

778

779

780

781

782

783

784

785

786

787

788

789

790

791

792

793

In a rapidly changing Arctic climate, with increased sea surface temperatures, decreasing ice coverage and potentially enhanced primary production (Arrigo et al., 2008; Boé et al., 2009; Fabry et al., 2009), our observations have several implications for future work. Firstly, sharp changes in $p \mathrm{CO}_{2}$ and carbonate chemistry may have little effect on either total carbon fixation or the relative amount of particulate or dissolved phases, although longer term experiments are needed to test the effect of ocean acidification on such communities. Secondly, nutrient (NOx, dSi) and light limitation, through stronger seasonal growth cycles and/or enhanced stratification, could have a strong impact on DOC production, and potential OA effects on plankton communities should be examined in this context in terms of multi-stressors. Lastly, there is a potentially important role of diatoms in PP and DOC production in the Arctic that needs further examination.

\section{Acknowledgements}

We acknowledge the UK Natural Environmental Research Council (NERC; Grant references NE/H017097/1 and NE/H017348/1), Department of Environment, Food and Rural Affairs (Defra), and Department of Energy and Climate Change (DECC) for funding the research cruise via the UK Ocean Acidification research programme, and to the Danish, Icelandic and Norwegian diplomatic authorities for granting permission to travel and work in Greenland, Iceland and Svalbard coastal and offshore waters. Two anonymous reviewers are thanked for their constructive comments on a previous draft of the paper.

\section{References}

Anderson, L.G., 2002. DOC in the Arctic Ocean. In: Hansell, D.A., Carlson, C.A. (Eds) Biogeochemistry of Marine Dissolved Organic Matter. Academic Press Inc., 665-683.

Arrigo, K.R., van Dijken, G., Pabi, S., 2008. Impact of shrinking Arctic ice cover on marine primary production. Geophys. Res. Lett., 35, L19603.

Boé, J., Hall, A., Qu, X., 2009. September sea-ice cover in the Arctic Ocean projected to vanish by 2100. Nat Geoscience 2, 341-343.

Bibby, T.S., Moore, C.M., 2011. Silicate: nitrate ratios of upwelled waters control the phytoplankton community sustained by mesoscale eddies in sub-tropical North Atlantic and Pacific. Biogeosci. 8, 657-666.

Brzezinski, M.A., 1985. The Si:C:N ratio of marine diatoms: interspecific variability and the effect of some environmental variables. J. Phycol. 21, 347-357.

Cole, J.J., Likens, G.E., Strayer, D.L., 1982. Photosynthetically produced dissolved organic-carbon and important carbon source for planktonic bacteria. Limnol. Oceanogr., 27, 1080-1090.

Czerny, J., Schulz, K.G., Boxhammer, T., Bellerby, R.G.J., Büdenbender, J., Engel, A., Krug, S.A., Ludwig, A., Nachtigall, K., Nondal, G., Niehoff, B., Silyakova, A., Riebesell, U., 2013. 
Implications of elevated CO2 on pelagic carbon fluxes in an Arctic mesocosm study - an elemental mass balance approach. Biogeosci., 10, 3109-3125.

Dickson, A. G., 1990a. Thermodynamics of the dissociation of boric acid in synthetic sea water from 273.15 to $318.15 \mathrm{~K}$. Deep-Sea Res., 37, 755-766.

Dickson, A. G., 1990b. Standard potential of the reaction: $\mathrm{AgCl}(\mathrm{s})+1 / 2 \mathrm{H}_{2}(\mathrm{~g})=\mathrm{Ag}(\mathrm{s})+\mathrm{HCl}(\mathrm{aq})$, and the standard acidity constant of the ion $\mathrm{HSO}_{4}{ }^{-}$in synthetic seawater from 273.15 to 318.15 K. J. Chem. Thermodyn., 22, 113-127.

del Giorgio, P.A., Cole, J.J., 1998. Bacterial growth efficiency in natural aquatic systems. Annu. Rev. Ecol. Syst., 29, 503-541.

Engel, A., 2002. Direct relationship between $\mathrm{CO}_{2}$ uptake and transparent exopolymer particles production in natural phytoplankton. Deep-Sea Res. 24(1), 49-53.

Engel, A., Delille, B., Jacquet, S., Riebesell, U., Rochelle-Newall, E., Terbrüggen, A., Zondervan, I., 2004. Transparent exopolymer particles and dissolved organic carbon production by Emiliania huxleyi exposed to different $\mathrm{CO}_{2}$ concentrations: a mesocosm experiment. Aquatic Microbial Ecol. 34, 93-104.

Engel, A., Borchard, C., Piontek, J., Schulz, K.G., Riebesell, U., Bellerby, R., 2013. $\mathrm{CO}_{2}$ increases ${ }^{14} \mathrm{C}$ primary production in an Arctic plankton community. Biogeosciences 10, 1291-1308.

Engel, A., Piontek, J., Grossart, H.-P., Riebesell, U., Schulz, K.G., Sperling, M., 2014. Impact of $\mathrm{CO}_{2}$ enrichment on organic matter dynamics during nutrient induced coastal phytoplankton blooms. J. Plankton Res. 36(3), 641-657.

Fabry, V.J., McClintock, J.B., Mathis, J.T., Grebmeier, J.M., 2009. Ocean acidification at high latitudes: The bellwether. Oceanography 22, 161-171.

Fouilland, E., Tolosa, I., Bonnet, D., Bouvier, C., Bouvier, T., Bouvy, M., Got, P., Le Floc'h, E., Mostajir, B., Roques, C., Sempéré, R., Sime-Ngando, T., Vidussi, F., 2014. Bacterial carbon dependence on freshly produced phytoplankton exudates under different nutrient availability and grazing pressure conditions in coastal marine waters. FEMS Microbial Ecol. 87, 757-769.

García-Martín, E.E., McNeill, S., Serret, P., Leakey, R.J.G., 2014a. Plankton metabolism and bacterial growth efficiency in offshore waters along a latitudinal transect between the UK and Svalbard. Deep-Sea Res. I 92, 141-151.

García-Martín, E.E., Serret, P., Leakey, R.J.G., 2014b. Plankton community and bacterial metabolism in Arctic sea ice leads during summer 2010. Deep-Sea Res. I. 92, 152-161.

Gattuso, J.-P., Lee, K., Rost, B., Schulz, K., Gao, K., 2010. Approaches and tools to manipulate the carbonate chemistry, in: Guide to best practices for ocean acidification research and data reporting, Riebesell, U., Fabry, V.J., Hansson, L., Gattuso, J.-P. (eds). Luxembourg, Publications Office of the European Union.

Gosselin, M., Levasseur, M., Wheeler, P.A., Horner, R.A., Booth, B.C., 1997. New measurements of phytoplankton and ice algal production in the Arctic Ocean. Deep-Sea Res. II 44, 1623-1644. 
Grasshoff, K., Ehrhardt, M., Kremling, K., 1983. Methods of seawater analysis. Weinhem, Verlag Chemie.

Hansell, D.A., 2002. DOC in the global ocean carbon cycle. In: Hansell, D.A., Carlson, C.A. (Eds) Biogeochemistry of Marine Dissolved Organic Matter. Academic Press Inc., 685-715.

Hansell, D.A., Carlson, C.A., 2015. DOM sources, sinks, reactivity and budgets, p. 65-126. In: Hansell, D.A., Carlson, C.A. (eds), Biogeochemistry of marine dissolved organic matter, $2^{\text {nd }}$ edition, Academic Press.

Karl, D.M., Hebel, D.V., Bjorkman, K., Letelier, R.M., 1998. The role of dissolved organic matter release in the productivity of the oligotrophic North Pacific Ocean. Limnol. Oceanogr., 43, 12701286.

Kiørbe, T., 1993. Turbulence, phytoplankton cell size, and the structure of the pelagic food webs. Adv. Mar. Biol., 29, 1-72.

Lagaria, A., Psarra, S., Gogou, A., Tuğrul, S., Christaki, U., 2013. Particulate and dissolved primary production along a pronounced hydrographic and trophic gradient (Turkish Straits System-NE Aegean Sea). J. Mar. Sys. 119-120, 1-10.

Le Moigne, F.A.C., Poulton, A.J., Henson, S.A., Daniels, C.J., Fragoso, G.M., Mitchell, E., Richier, S., Russell, B.C., Smith, H.E.K., Tarling, G.A., Young, J.R., Zubkov, M., 2015. Carbon export efficiency and phytoplankton community composition in the Atlantic sector of the Arctic Ocean. J. Geophys. Res., in press.

Lee, K., Kim, T.-W., Byrne, R. H., Millero, F. J., Feely, R. A., Liu, Y.-M., 2010. The universal ratio of boron to chlorinity for the North Pacific and North Atlantic oceans. Geochimica et Cosmochim. Acta, 74, 1801-1811.

Lee, S., Fuhrman, J.A., 1987. Relationships between biovolume and biomass of naturally derived marine bacterioplankton. Applied. Env. Microbiol. 53(6), 1298-1303.

López-Sandoval, D.C., Fernández, A., Marañón, E., 2011. Dissolved and particulate primary production along a longitudinal gradients in the Mediterranean Sea. Biogeosciences 8, 815-825.

Lueker, T. J., Dickson, A. G., Keeling, C. D., 2000. Ocean $\mathrm{pCO}_{2}$ calculated from dissolved inorganic carbon, alkalinity, and equations for $\mathrm{K}_{1}$ and $\mathrm{K}_{2}$ : validation based on laboratory measurements of $\mathrm{CO}_{2}$ in gas and seawater at equilibrium. Mar. Chem., 70, 1801-1811.

MacGilchrist, G.A., Shi, T., Tyrrell, T., Richier, S., Moore, C.M., Dumousseaud, C., Achterberg, E.P., 2014. Effect of enhanced $\mathrm{pCO}_{2}$ levels on the production of dissolved organic carbon and transparent exopolymer particles in short-term bioassay experiments. Biogeosci., 11, 36953706.

Marañón, E., Cermeño, P., Fernández, E., Rodríguez, J., Zabala, L., 2004. Significance and mechanisms of photosynthetic production of dissolved organic matter in a coastal eutrophic ecosystem. Limnol. Oceanogr., 49, 1652-1666. 
Marañón, E., Cermeño, P., Pérez, V., 2005. Continuity in the photosynthetic production of dissolved organic carbon from eutrophic to oligotrophic waters. Mar. Ecol. Prog. Ser. 299, 7-17.

Maugendre, L., Gattuso, J.-P., Poulton, A.J., Dellisanti, W., Gaubert, M., Guieu, C., Gazeau, F., 2015. No detectable effect of ocean acidification on the plankton metabolism in the north west Mediterranean Sea: results from two mesocosm studies. Estuarine, Coastal and Shelf Science, in press.

Moore, C.M., Mills, M.M., Achterberg, E.P., Geider, R.J., LaRoche, J., Lucas, M.I., McDonagh, E.L., Pan, X., Poulton, A.J., Rijkenberg, M.J.A., Suggett, D.J., Ussher, S.J., Woodward, E.M.S., 2009. Large-scale distribution of Atlantic nitrogen fixation controlled by iron availability. Nat. Geosci. 2, 867-871.

Morán, X.A.G., Estrada, M., Gasol, J.M., Pedrós-Alió, C., 2002a. Dissolved primary production and the strength of phytoplankton bacterioplankton coupling in contrasting marine regions. Microb. Ecol., 44, 217-223.

Morán, X.A.G., Gasol, J.M., Pedrós-Alió, C., Estrada, M., 2002b. Dissolved and particulate primary production and bacterial production in offshore Antarctic waters during austral summer: coupled or uncoupled? Mar. Ecol. Prog. Ser. 222, 25-39.

Nagata, T., 2000. Production mechanisms of dissolved organic matter. In: Kirchman, D.L. (ed) Microbial ecology of the oceans. John Wiley \& Sons, Chichester, p 121-152.

Norrman, B., Zweifel, U.L., Hopkinson, C.S., Fry, B., 1995. Production and utilization of dissolved organic carbon during an experimental diatom bloom. Limnol. Oceanogr. 40, 898-907.

Poulton, A.J., Stinchcombe, M.C., Achterberg, E.P., Bakker, D.C.E., Dumousseaud, C., Lawson, H.E., Lee, G.A., Richier, S., Suggett, D.J., Young, J.R., 2014. Coccolithophores on the northwest European shelf: calcification rates and environmental controls. Biogeosci., 11, 3919-3940.

Ragueneau, O., Treguer, P., 1994. Determination of silica in coastal waters - applicability and limits of the alkaline digestion method. Mar. Chem. 45, 43-51.

Richier, S., Achterberg, E.P., Dumousseaud, C., Poulton, A.J., Suggett, D.J., Tyrrell, T., Zubkov, M.V., Moore, C.M., 2014. Carbon cycling and phytoplankton responses within highly-replicated shipboard carbonate chemistry manipulation experiments conducted around north-west European shelf seas. Biogeosci., 11, 4733-4752.

Rivkin, R.B., Legendre, L., 2001. Biogenic carbon cycling in the upper ocean: effects of microbial respiration. Science 291, 2398-2400.

Robinson, C., 2008. Heterotrophic bacterial respiration. In: Kirchman, DL (Ed) Microbial Ecology of the Oceans. John Wiley and Sons, Inc. 299-334.

Royal Society, 2005. Ocean acidification due to increasing atmospheric carbon dioxide. The Royal Society, London. 
902

903

904

905

906

907

908

909

910

911

912

913

914

915

916

917

918

919

920

921

922

923

924

925

926

927

928

929

930

931

932

933

Tarling, G.A., Peck, V., Ward, P., Ensor, N., Achterberg, E.A., Tynan, E., Poulton, A.J., Zubkov, M.V., Leakey, R.J., 2015. Effects of ocean acidification on polar planktonic food webs - a spatially-extensive microcosm approach. Deep-Sea Res., this issue.

Teira, E., Pazó, M.J., Serret, P., Fernández, E., 2001. Dissolved organic carbon production by microbial populations in the Atlantic Ocean. Limnol. Oceanogr. 46, 1370-1377.

Teira, E., Pazo, M.J., Quevedo, M., Fuentes, M.V., Niell, F.X., Fernandez, E., 2003. Rates of dissolved carbon production and bacterial activity in the eastern North Atlantic Subtropical Gyre during summer. Mar. Ecol. Prog. Ser. 249, 53-67.

Tynan, E., Ribas-Ribas, M., Clarke, J.S., Humphreys, M.P., Rerolle, V.M.C., Esposito, M., Thorpe, S.E., Tyrrell, T., Achterberg, E.P. (this issue). Physical and biogeochemical controls on the variability in surface carbonate chemistry in the Arctic and Southern Oceans. Deep-Sea Research II.

Van Heuven, S., Pierrot, D., Rae, J. W. B., Lewis, E., Wallace, D. W. R., 2011. CO2SYS v 1.1, MATLAB program developed for $\mathrm{CO}_{2}$ system calculations. ORNL/CDIAC-105b. Carbon Dioxide Information Analysis Center, O. R. N. L., U.S DoE, Oak Ridge, TN (Ed.).

Wear, E.K., Carlson, C.A., James, A.K., Brzezinski, M.A., Windecker, L.A., Nelson, C.E., 2015.

Synchronous shifts in dissolved organic carbon bioavailability and bacterial community responses over the course of an upwelling-driven phytoplankton bloom. Limnol. Oceanogr. 60, 657-677.

Wetz, M.S., Wheeler, P.A., 2007. Release of dissolved organic matter by coastal diatoms. Limnol. Oceanogr. 52(2), 798-807.

Yoshimura, T., Niskioka, J., Suzuki, K., Hattori, H., Kiyosawa, H., Watanabe, Y.W., 2010. Impacts of elevated $\mathrm{CO} 2$ on organic carbon dynamics in nutrient depleted Okhotsk Sea surface waters. J. Exp. Mar. Biol. Ecol. 395, 191-198.

Yoshimura, T., Suzuki, K., Kiyosawa, H., Ono, T., Hattori, H., Kuma, K., Nishioka, J., 2013. Impacts of elevated $\mathrm{CO}_{2}$ on particulate and dissolved organic matter production: microcosm experiments using iron-deficient plankton communities in open subarctic waters. J. Oceanogr. 69, 601-618.

Zubkov, M.V., Burkill P.H., 2006. Syringe pumped high speed flow cytometry of oceanic phytoplankton. Cytometry Part A, 69, 1010-1019.

Zubkov, M.V., Sleigh, M.A., Burkill, P.H., Leakey, R.J.G., 2000. Bacterial growth and grazing loss in contrasting areas of North and South Atlantic. J. Plankt. Res. 22, 685-711. 
Table 1. Oceanographic characteristics of the sampling stations, including CTD number, date sampled, latitude and longitude, sampling location, sampling depth, surface temperature, salinity, euphotic zone depth $\left(\mathrm{Z}_{\text {eup }}\right), \mathrm{pCO}_{2}, \mathrm{pH}$, nitrate $(\mathrm{NOx})$ and silicic acid (dSi) concentration, nitrate to phosphate ratio $\left(\mathrm{N}^{*}\right)$, silicate to nitrate ratio $\left(\mathrm{Si}^{*}\right)$ and incidental irradiance $\left(\operatorname{Ed}_{[0+]}\right)$.

940

Table 2. Surface biogeochemistry of sampling stations, including CTD number, sampling location,

942 total and microplankton (>10 $\mu \mathrm{m}$ ) chlorophyll (Chl), primary production (PP), DOC production

$943(p D O C)$, percentage extracellular release (PER), bacterial production (BP), bacterial carbon

944 demand $(B C D)$, ratio of $p D O C$ to $B C D$, bacterial biomass $\left(\mathrm{C}_{\text {bact }}\right)$ and particulate silica $\left(\mathrm{bSiO}_{2}\right)$. a

945 indicates in situ sample incubated in temperature controlled refrigerated container rather than on-

946 deck (see methods). Standard deviations are given in brackets for $p D O C$ and PP.

947

948 Table 3. Average initial conditions for the three bioassay experiments. Standard errors are given in 949 brackets.

950

951 Table 4. Average values of estimated bacterial carbon demand (BCD) in $p \mathrm{CO}_{2}$ manipulation 952 experiments for ambient and $1000 \mu$ atm treatments. Standard errors are given in brackets. NA 953 indicates not available. 
Table 1.

956

\begin{tabular}{|c|c|c|c|c|c|c|c|c|c|c|c|c|c|c|c|}
\hline CTD & Date & $\begin{array}{l}\text { Lat. } \\
{\left[{ }^{\circ} \mathrm{N}\right]}\end{array}$ & $\begin{array}{l}\text { Long. } \\
{\left[{ }^{\circ} \mathrm{W}\right]}\end{array}$ & Location & $\begin{array}{c}\text { Depth } \\
\text { [m] }\end{array}$ & $\begin{array}{c}\text { Temp. } \\
{\left[{ }^{\circ} \mathrm{C}\right]}\end{array}$ & Salinity & $\begin{array}{l}Z_{\text {eup }} \\
{[\mathrm{m}]}\end{array}$ & 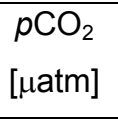 & $\mathrm{pH}$ & $\begin{array}{l}\text { NOx } \\
{[\mu \mathrm{mol}}\end{array}$ & $\begin{array}{l}\text { dSi } \\
\left.g^{-1}\right]\end{array}$ & $\mathrm{N}^{*}$ & $\mathrm{Si}^{*}$ & $\begin{array}{c}\mathrm{Ed}_{[0+]} \\
\text { [mol photons } \\
\mathrm{m}^{-2} \mathrm{~d}^{-1} \text { ] }\end{array}$ \\
\hline C019 & 10 Jun & $65.59^{\circ} \mathrm{N}$ & $10.43^{\circ} \mathrm{W}$ & Iceland - Faroes Front (N) & 24 & 3.6 & 34.8 & 32 & 240 & 8.2 & 0.6 & 2.5 & -3.0 & 1.9 & 34 \\
\hline C020 & 11 Jun & $69.54^{\circ} \mathrm{N}$ & $07.35^{\circ} \mathrm{W}$ & Greenland Sea (S) & 15 & 3.1 & 35.0 & 38 & 363 & 8.1 & 9.1 & 6.1 & -1.2 & -3.0 & 53 \\
\hline C021 & 12 Jun & $74.07^{\circ} \mathrm{N}$ & $04.42^{\circ} \mathrm{W}$ & Greenland Sea (C) & 15 & 1.0 & 34.9 & 60 & 308 & 8.1 & 9.8 & 5.7 & -1.4 & -4.0 & 40 \\
\hline $\mathrm{C} 027$ & 13 Jun & $76.11^{\circ} \mathrm{N}$ & $02.33^{\circ} \mathrm{W}$ & Greenland Sea (N) & 20 & 1.5 & 34.9 & ND & 319 & 8.1 & 9.3 & 4.7 & -1.4 & -4.6 & 42 \\
\hline C029 & 14 Jun & $78.43^{\circ} \mathrm{N}$ & $-00.00^{\circ} \mathrm{E}$ & Ice edge & 10 & 3.5 & 35.0 & 21 & 209 & 8.3 & 2.6 & 5.5 & -2.4 & 2.9 & 51 \\
\hline C032 & 16 Jun & $78.13^{\circ} \mathrm{N}$ & $05.60^{\circ} \mathrm{W}$ & Ice & 10 & -1.5 & 32.5 & ND & 381 & 8.0 & 6.6 & 8.0 & -3.7 & 1.5 & 51 \\
\hline $\mathrm{C} 033$ & 17 Jun & $77.49^{\circ} \mathrm{N}$ & $04.58^{\circ} \mathrm{W}$ & Ice & 14 & -1.6 & 33.0 & 66 & 350 & 8.1 & 6.4 & 7.0 & -2.4 & 0.6 & 38 \\
\hline $\mathrm{C} 040$ & 19 Jun & $77.51^{\circ} \mathrm{N}$ & $01.18^{\circ} \mathrm{W}$ & Ice edge & 15 & 3.1 & 34.9 & 28 & 309 & 8.1 & 8.7 & 5.6 & -1.2 & -3.1 & 20 \\
\hline $\mathrm{C} 042$ & 20 Jun & $78.59^{\circ} \mathrm{N}$ & $-07.59^{\circ} \mathrm{E}$ & Fram Strait & 15 & 6.0 & 35.1 & 22 & 208 & 8.3 & 4.0 & 4.3 & -2.1 & 0.4 & 28 \\
\hline $\mathrm{C} 045$ & 22 Jun & $76.16^{\circ} \mathrm{N}$ & $-12.32^{\circ} \mathrm{E}$ & Norwegian Sea $(\mathrm{N})$ & 20 & 5.7 & 35.2 & 39 & 309 & 8.1 & 9.8 & 5.8 & -1.8 & -4.0 & 19 \\
\hline $\mathrm{C} 047$ & 23 Jun & $76.09^{\circ} \mathrm{N}$ & $-26.04^{\circ} \mathrm{E}$ & Barents Sea $(N)$ & 25 & 1.5 & 34.6 & 70 & 238 & 8.2 & 0.2 & 1.2 & -2.7 & 1.0 & 27 \\
\hline C052 & 24 Jun & $72.53^{\circ} \mathrm{N}$ & $-26.00^{\circ} \mathrm{E}$ & Barents Sea (S) & 15 & 6.5 & 35.0 & 67 & 324 & 8.1 & 7.8 & 4.4 & -1.2 & -3.4 & 20 \\
\hline $\mathrm{C} 054$ & 25 Jun & $71.45^{\circ} \mathrm{N}$ & $-17.54^{\circ} \mathrm{E}$ & Barents Sea (S) & 13 & 7.8 & 35.0 & 62 & 320 & 8.1 & 6.0 & 3.8 & -1.8 & -2.2 & 24 \\
\hline $\mathrm{C} 056$ & 26 Jun & $71.45^{\circ} \mathrm{N}$ & $-08.27^{\circ} \mathrm{E}$ & Norwegian Sea (C) & 15 & 6.7 & 35.2 & 32 & 305 & 8.1 & 6.8 & 5.2 & -1.2 & -1.6 & 33 \\
\hline $\mathrm{C} 060$ & 28 Jun & $71.45^{\circ} \mathrm{N}$ & $10.36^{\circ} \mathrm{W}$ & Greenland Sea (S) & 26 & 1.4 & 34.7 & 55 & 328 & 8.1 & 8.6 & 2.2 & -1.6 & -6.5 & 49 \\
\hline $\mathrm{C} 063$ & 29 Jun & $68.42^{\circ} \mathrm{N}$ & $10.35^{\circ} \mathrm{W}$ & Greenland Sea (S) & 20 & 3.8 & 34.8 & 43 & 318 & 8.1 & 8.9 & 2.6 & -1.5 & -6.3 & 40 \\
\hline $\mathrm{C} 065$ & 30 Jun & $67.50^{\circ} \mathrm{N}$ & $16.25^{\circ} \mathrm{W}$ & Iceland $(\mathrm{N})$ & 20 & 5.1 & 34.9 & 48 & 246 & 8.2 & 4.0 & 4.1 & -2.8 & 0.0 & 33 \\
\hline
\end{tabular}


Table 2.

959

\begin{tabular}{|c|c|c|c|c|c|c|c|c|c|c|c|}
\hline CTD & Location & $\begin{array}{c}\text { Total } \\
\text { Chl } \\
{\left[\mathrm{mg} \mathrm{m}^{-3}\right]}\end{array}$ & $\begin{array}{c}>10 \mu \mathrm{m} \\
\mathrm{Chl} \\
{[\%]}\end{array}$ & \multicolumn{2}{|c|}{$\left[\mathrm{mmol} \mathrm{C} \mathrm{m} \mathrm{m}^{-3} \mathrm{~d}^{-1}\right]$} & $\begin{array}{c}\text { PER } \\
{[\%]}\end{array}$ & $\begin{array}{l}\text { BP } \\
{[\mathrm{mmol}}\end{array}$ & $\begin{array}{c}\text { BCD } \\
\left.\mathrm{C} \mathrm{m}^{-3} \mathrm{~d}^{-1}\right]\end{array}$ & $\begin{array}{c}p D O C / B C D \\
{[\%]}\end{array}$ & $\begin{array}{c}\mathrm{C}_{\text {bact }} \\
{\left[\mathrm{mmol} \mathrm{C} \mathrm{m}{ }^{-3}\right]}\end{array}$ & $\begin{array}{c}\mathrm{bSiO}_{2} \\
{\left[\mathrm{mmol} \mathrm{Si} \mathrm{m}^{-3}\right]}\end{array}$ \\
\hline C019 & Iceland - Faroes Front (N) & 6.2 & 50 & $3.7(0.1)$ & $0.44(0.20)$ & 11 & 1.38 & 5.8 & 8 & 3.8 & 1.1 \\
\hline $\mathrm{C} 020$ & Greenland Sea (S) & 2.1 & 31 & $1.1(0.2)$ & $0.21(-)$ & 16 & 0.16 & 1.4 & 15 & 1.7 & 0.2 \\
\hline $\mathrm{C} 021$ & Greenland Sea (C) & 0.7 & 20 & $0.9(0.1)$ & $0.18(0.08)$ & 17 & 0.23 & 1.8 & 10 & 2.4 & 0.3 \\
\hline $\mathrm{C} 027$ & Greenland Sea (N) & 1.3 & & $2.2(0.1)$ & $0.16(0.01)$ & 7 & 0.19 & 1.6 & 10 & 1.6 & 0.4 \\
\hline $\mathrm{C} 029$ & lce edge & 8.4 & 32 & $3.8(0.3) a$ & $0.17(0.04) a$ & $4^{a}$ & 0.36 & 2.4 & 7 & 1.8 & 0.7 \\
\hline $\mathrm{C} 030$ & Ice & 1.0 & 14 & $1.1(0.1)$ & $0.24(0.09)$ & 18 & 0.11 & 1.1 & 22 & 0.6 & 0.2 \\
\hline C032 & Ice & 0.5 & 19 & $0.8(0.1)$ & $0.15(0.07)$ & 16 & 0.07 & 0.8 & 18 & 0.5 & 0.2 \\
\hline C033 & Ice & 0.5 & 15 & $0.9(0.2)$ & $0.10(0.00)$ & 10 & 0.05 & 0.7 & 14 & 0.5 & 0.7 \\
\hline $\mathrm{C} 040$ & Ice edge & 3.1 & 34 & $5.2(0.5)$ & $0.21(0.02)$ & 4 & 0.48 & 2.9 & 7 & 1.9 & \\
\hline $\mathrm{C} 042$ & Fram Strait & 4.3 & 5 & $3.9(0.8)$ & $0.09(0.01)$ & 2 & 0.30 & 2.1 & 4 & 0.9 & 0.4 \\
\hline $\mathrm{C} 045$ & Norwegian Sea $(\mathrm{N})$ & 2.0 & 8 & $1.8(0.4)$ & $0.24(0.14)$ & 12 & 0.13 & 1.3 & 19 & 2.0 & 0.2 \\
\hline $\mathrm{C} 047$ & Barents Sea (Ice) & 0.4 & 5 & $0.4(0.0)$ & $0.34(0.09)$ & 46 & 0.35 & 2.4 & 14 & 0.5 & 0.1 \\
\hline $\mathrm{C} 052$ & Barents Sea (S) & 1.3 & 2 & $1.5(0.3)$ & $0.33(0.20)$ & 18 & 0.12 & 1.2 & 28 & 1.8 & $<0.1$ \\
\hline C054 & Barents Sea (S) & 1.0 & 6 & $1.5(0.2)$ & $0.64(0.52)$ & 30 & 0.17 & 1.5 & 43 & 2.2 & 0.3 \\
\hline $\mathrm{C} 056$ & Norwegian Sea (C) & 2.0 & 37 & $2.3(1.2)$ & $0.17(0.10)$ & 7 & 0.20 & 1.6 & 10 & 6.4 & 0.2 \\
\hline $\mathrm{C} 058$ & Norwegian Sea (C) & 1.0 & & $3.9(0.2)$ & $0.15(0.04)$ & 4 & 0.36 & 2.4 & 6 & 3.0 & 0.6 \\
\hline $\mathrm{C} 060$ & Greenland Sea (S) & 1.5 & 23 & $1.1(1.2)$ & $0.33(0.16)$ & 23 & 0.27 & 2.0 & 16 & 2.8 & 0.4 \\
\hline $\mathrm{C} 063$ & Greenland Sea (S) & 1.3 & 43 & $1.6(0.3)$ & $0.48(0.11)$ & 23 & 0.27 & 2.0 & 24 & 5.2 & 0.2 \\
\hline \multirow[t]{4}{*}{ C065 } & Iceland $(\mathrm{N})$ & 0.8 & 18 & $1.4(0.2)$ & $0.39(0.02)$ & 22 & 0.11 & 1.1 & 34 & 1.2 & 3.7 \\
\hline & MEAN & 2.1 & 21 & 2.1 & 0.26 & 15 & 0.28 & 1.9 & 16 & 2.2 & 0.6 \\
\hline & MIN & 0.4 & 2 & 0.4 & 0.09 & 2 & 0.05 & 0.7 & 4 & 0.5 & $<0.1$ \\
\hline & MAX & 8.4 & 50 & 5.2 & 0.64 & 46 & 1.38 & 5.8 & 23 & 6.4 & 3.7 \\
\hline
\end{tabular}


961

962

\begin{tabular}{lccc}
\hline Parameter & EB02 & EB03 & EB04 \\
\hline & Iceland & Ice & Greenland Ice \\
Location & Basin & Edge & Sheet \\
& $60^{\circ} 35.62^{\prime} \mathrm{N}$ & $76^{\circ} 10.51^{\prime} \mathrm{N}$ & $78^{\circ} 21.15^{\prime} \mathrm{N}$ \\
Latitude & $018^{\circ} 51.39^{\prime} \mathrm{W}$ & $002^{\circ} 32.96^{\prime} \mathrm{W}$ & $003^{\circ} 39.85^{\prime} \mathrm{W}$ \\
Longitude & $310[7]$ & $289[10]$ & $305[0.3]$ \\
$\mathrm{pCO}_{2}(\mu \mathrm{atm})$ & $8.14[0.01]$ & $8.16[0.02]$ & $8.13[0.01]$ \\
$\mathrm{pH}_{\mathrm{T}}$ & $10.62[0.06]$ & $1.68[0.01]$ & $-1.57[0.04]$ \\
$\mathrm{SST}\left({ }^{\circ} \mathrm{C}\right)$ & $35.2[0.0]$ & $34.9[0.0]$ & $32.6[0.0]$ \\
Salinity & $5.02[0.09]$ & $9.52[0.50]$ & $4.19[0.17]$ \\
Nitrate $\left(\mu \mathrm{mol} \mathrm{N} \mathrm{kg}{ }^{-1}\right)$ & $1.56[0.18]$ & $3.77[0.32]$ & $10.30[0.03]$ \\
Silicic acid $\left(\mu \mathrm{mol} \mathrm{Si} \mathrm{kg}^{-1}\right)$ & & & \\
& & & \\
\hline
\end{tabular}

963

964 
966

\begin{tabular}{cccccc}
\hline Bioassay & Treatment & Time point & $\begin{array}{c}\mathrm{BCD} \\
{\left[\mathrm{mmol} \mathrm{C} \mathrm{m}^{-3} \mathrm{~d}^{-1}\right]}\end{array}$ & $\begin{array}{c}\mathrm{pDOC} / \mathrm{BCD} \\
{[\%]}\end{array}$ & $\begin{array}{c}\mathrm{NOx} \\
{\left[\mu \mathrm{mol} \mathrm{N} \mathrm{kg}{ }^{-1}\right]}\end{array}$ \\
\hline \multirow{3}{*}{ EB02 } & Initial & $\mathrm{T}_{0}$ & $0.96[0.06]$ & $\mathrm{NA}$ & $5.0[0.1]$ \\
& Ambient & $\mathrm{T}_{48}$ & $0.81[0.08]$ & $41[13]$ & $3.5[0.3]$ \\
& Ambient & $\mathrm{T}_{96}$ & $0.43[0.05]$ & $81[10]$ & $1.6[0.5]$ \\
& $1000 \mu$ atm & $\mathrm{T}_{48}$ & $0.82[0.06]$ & $86[23]$ & $3.6[0.1]$ \\
& $1000 \mu \mathrm{atm}$ & $\mathrm{T}_{96}$ & $0.41[0.01]$ & $159[54]$ & $1.7[0.2]$ \\
EB03 & Initial & $\mathrm{T}_{0}$ & $0.45[0.03]$ & $34[6]$ & $9.3[0.1]$ \\
& Ambient & $\mathrm{T}_{48}$ & $1.19[0.25]$ & $21[13]$ & $8.6[0.1]$ \\
& Ambient & $\mathrm{T}_{96}$ & $0.21[0.02]$ & $456[123]$ & $6.7[0.1]$ \\
& $1000 \mu$ atm & $\mathrm{T}_{48}$ & $1.97[0.39]$ & $7[1]$ & $8.5[0.1]$ \\
& $1000 \mu \mathrm{atm}$ & $\mathrm{T}_{96}$ & $0.33[0.03]$ & $33[11]$ & $6.9[0.2]$ \\
EB04 & Initial & $\mathrm{T}_{0}$ & $0.36[0.02]$ & $59[29]$ & $4.2[0.2]$ \\
& Ambient & $\mathrm{T}_{48}$ & $1.26[0.00]$ & $29[<1]$ & $1.3[0.3]$ \\
& Ambient & $\mathrm{T}_{96}$ & $0.60[0.01]$ & $545[59]$ & $0.1[<0.1]$ \\
& $1000 \mu \mathrm{atm}$ & $\mathrm{T}_{48}$ & $1.62[0.29]$ & $13[2]$ & $1.3[0.5]$ \\
& $1000 \mu \mathrm{atm}$ & $\mathrm{T}_{96}$ & $0.74[0.12]$ & $510[236]$ & $<0.1[<0.1]$ \\
& & & & & \\
\hline
\end{tabular}


968

969

970

971

972

973

974

975

976

977

978

979

980

981

982

983

984

985

986

987

988

989

990

991

992

993

994

995

996

997

998

999

1000

1001

1002

\section{FIGURE LEGENDS}

Fig. 1. Cruise track and sampling locations for field samples (circles) and bioassay experiments (stars) superimposed on composite (June 2012) satellite images of (A) sea ice extent (in blue) and topography, and (B) MODIS sea surface temperature. Sea ice concentration data from the Nimbus-7 SMMR and DMSP SSM/I-SSMIS passive microwave sensors were obtained from the National Snow and Ice Data Centre (www.nsidc.org). MODIS sea surface temperature data were obtained from the NASA Ocean Color distributed archive (http: //oceancolor.gsfc.gov/). Numbers in A indicate CTD positions (see Table 1).

Fig. 2. Surface rates. (A) Primary production (PP), (B) DOC production ( $p D O C)$, and (C) Percentage Extracellular Release (PER). Error bars are standard deviations $(n=3)$ from in situ measurements.

Fig. 3. Scatter plots of $D O C$ production $(p D O C, A-H)$ and percentage extracellular release (PER, IP) against environmental factors: (A, I) Sea-surface temperature (SST, $\left.{ }^{\circ} \mathrm{C}\right)$; $(B, J)$ Nitrate+nitrite concentration (NOx, $\mu \mathrm{mol} \mathrm{N} \mathrm{kg}{ }^{-1}$ ); (C, K) Ratio of nitrate(+nitrite) to phosphate as represented by

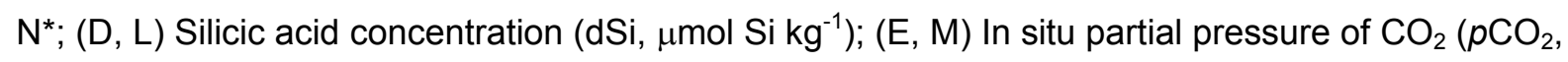
$\mu$ atm); $(\mathrm{F}, \mathrm{N}) \mathrm{pH}_{\mathrm{T}} ;(\mathrm{G}, \mathrm{O})$ Depth of the euphotic zone $\left(Z_{\text {eup }}, \mathrm{m}\right) ;(\mathrm{H}, \mathrm{P})$ Incidental irradiance $\left(\mathrm{Ed}_{[0+]}\right.$, mol photons $\left.\mathrm{m}^{-2} \mathrm{~d}^{-1}\right)$. Pearson-product moment correlation coefficients $(r)$ are given for significant $(p<0.05)$ correlations.

Fig. 4. Time series measurements of total chlorophyll (TChl, $\left.\mathrm{mg} \mathrm{m}^{-3}\right),>10 \mu \mathrm{m}$ chlorophyll $(>10 \mu \mathrm{m}$ $\left.\mathrm{Chl}, \mathrm{mg} \mathrm{m}^{-3}\right)$, NOx $\left(\mu \mathrm{mol} \mathrm{N} \mathrm{kg}^{-1}\right)$, silicic acid $\left(\mathrm{dSi}, \mu \mathrm{mol} \mathrm{Si} \mathrm{kg}{ }^{-1}\right)$ and particulate silica $\left(\mathrm{bSiO}_{2}, \mu \mathrm{mol} \mathrm{Si}\right.$ $\mathrm{kg}^{-1}$ ) for the three $\mathrm{pCO}_{2}$ bioassays (EB-02, EB-03, EB-04). Plotted values are means \pm standard errors (se) from triplicate sample bottles per treatment. Observation of any statistically significant differences between treatments (1-way ANOVA, $p<0.05)$ for each variable and time point are indicated by *.

Fig. 5. Time series measurements of dissolved organic carbon (DOC) production ( $p D O C, \mathrm{mmol} C$ $\mathrm{m}^{-3} \mathrm{~d}^{-1}$ ), primary production (PP, mmol $\mathrm{C} \mathrm{m}^{-3} \mathrm{~d}^{-1}$ ), percentage extracellular release (PER, \%), bacterial production (BP, mmol C m $\left.\mathrm{m}^{-3}\right)$ and heterotrophic bacteria biomass $\left(\mathrm{C}_{\text {bact }}, \mathrm{mmol} \mathrm{C} \mathrm{m}^{-3}\right)$ for the three $\mathrm{pCO}_{2}$ experiments (EB-02, EB-03, EB-04). Plotted values are means \pm se from triplicate sample bottles per treatment. Observation of any statistically significant differences between treatments ( 1 -way ANOVA, $p<0.05)$ for each variable and time point are indicated by *. 
1003

1004

1005

1006

1007

1008

1009

1010

1011

Fig. 6. Relative changes in (a,c) dissolved organic carbon (DOC) production ( $p D O C)$ and $(b, d)$ percentage extracellular release (PER) for two time points in $p \mathrm{CO}_{2}$ experiments $\left(\mathrm{T}_{48}: \mathrm{a}, \mathrm{b} ; \mathrm{T}_{96}: \mathrm{c}, \mathrm{d}\right)$. Errors bars are standard deviations across triplicate treatment bottles.

Fig. 7. Relative changes in dissolved organic carbon production ( $p D O C)$ and percentage extracellular release against $(a, c)$ NOx (nitrate+nitrite) drawdown and (b, d) silicic acid (dSi) drawdown in the three bioassay experiments. Errors bars are standard deviations across triplicate treatment bottles. 
Figure(s)

Figure 1
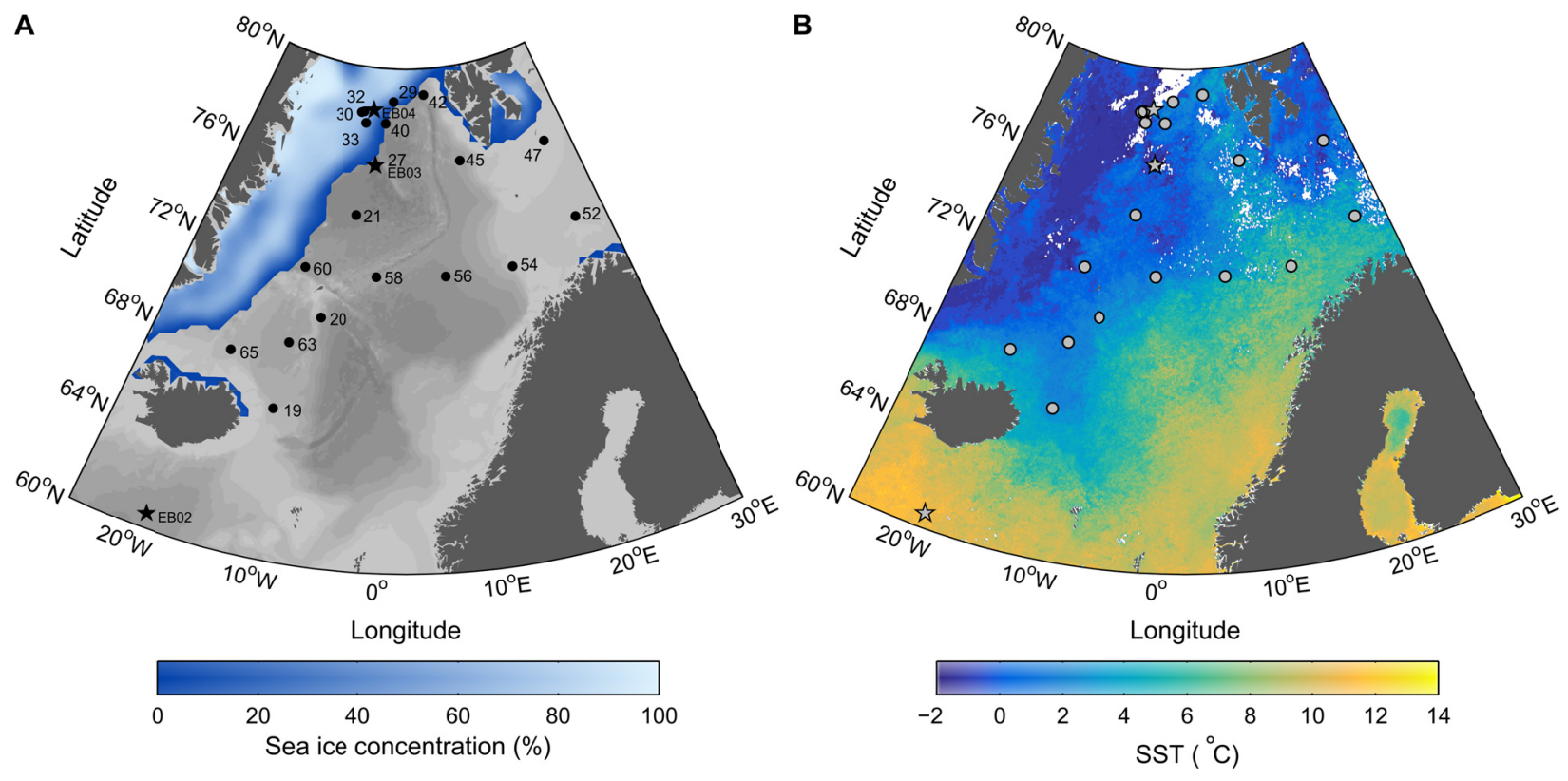
Figure 2
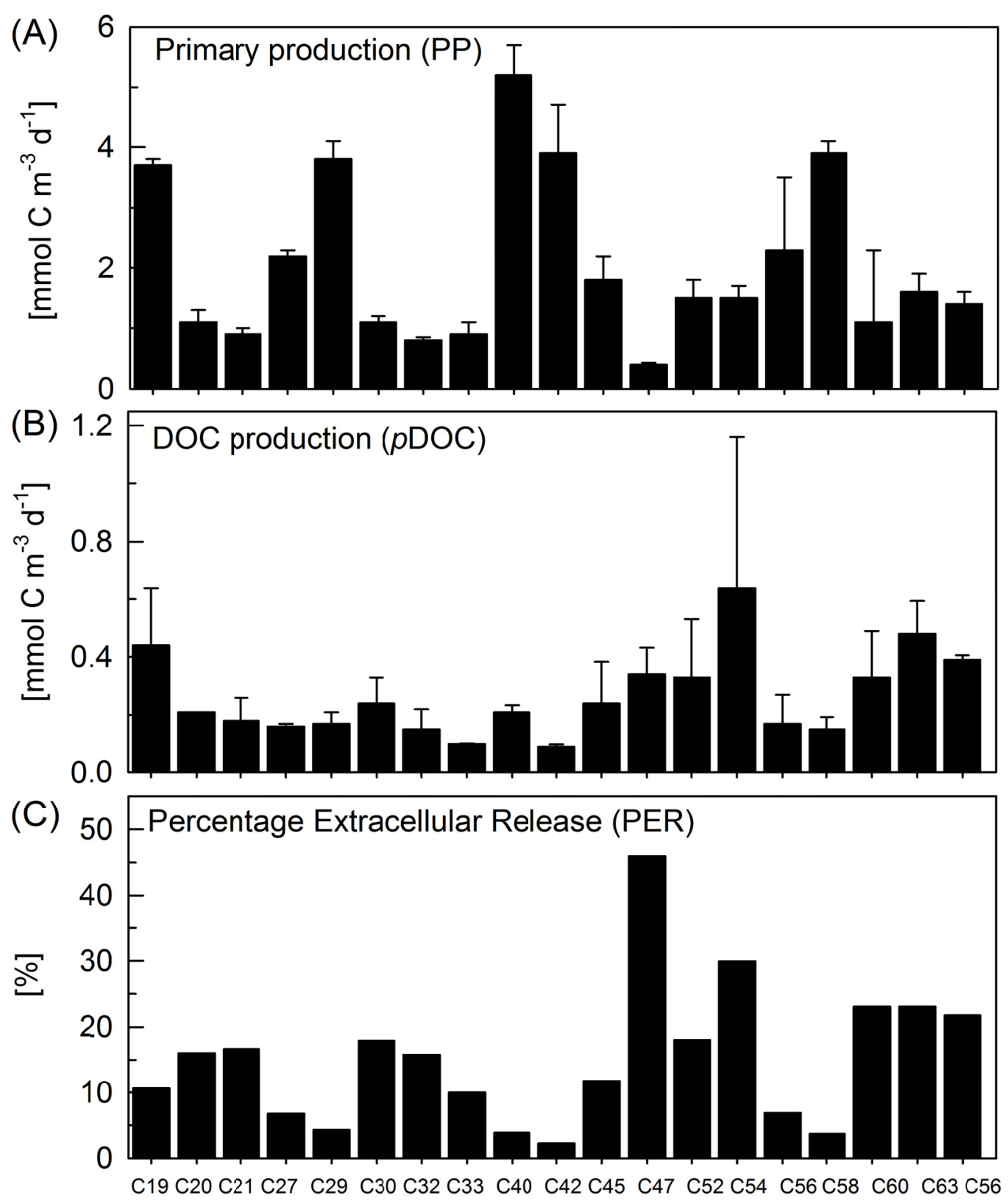

Sampling stations 
Figure 3
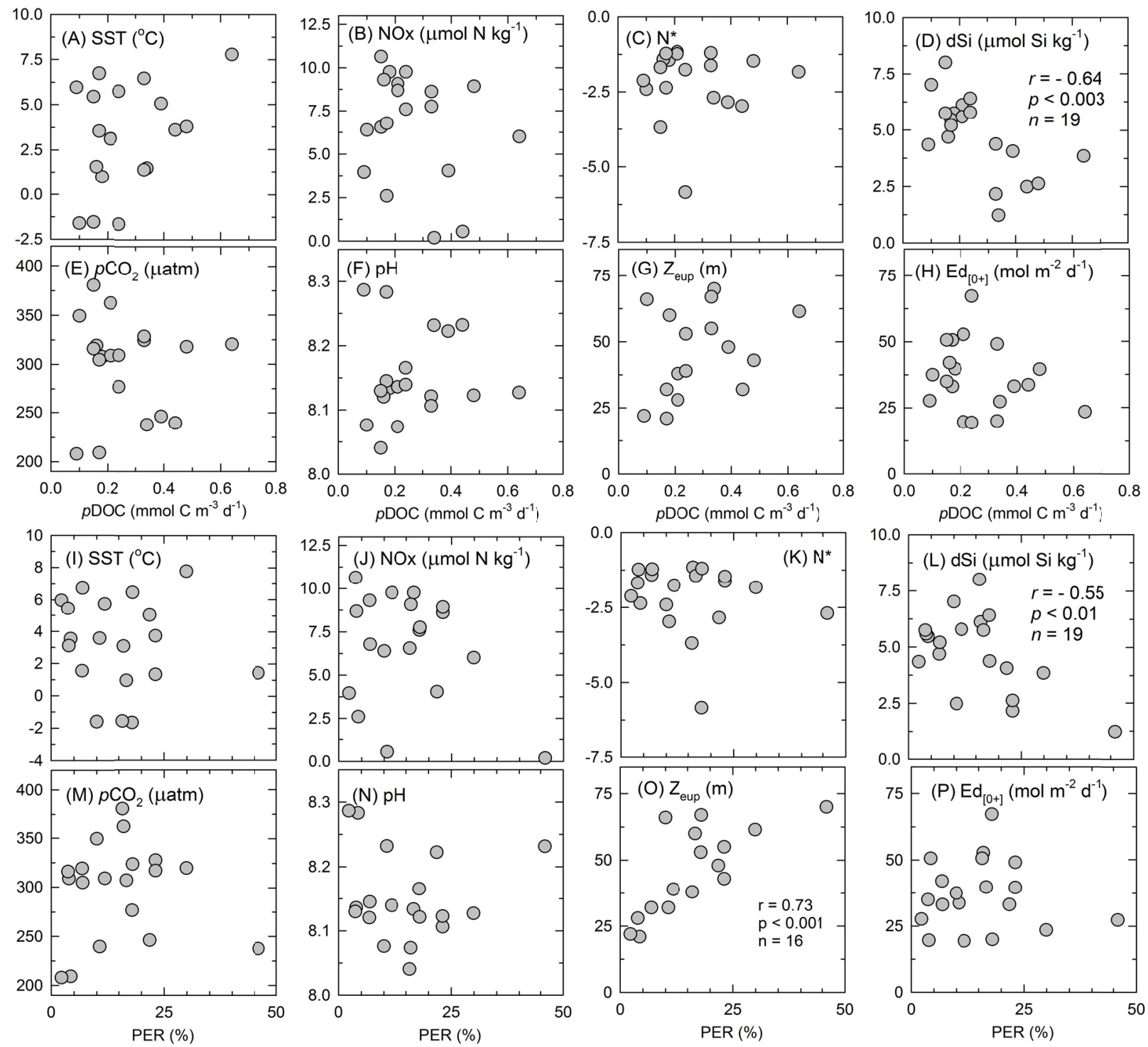
Figure 4
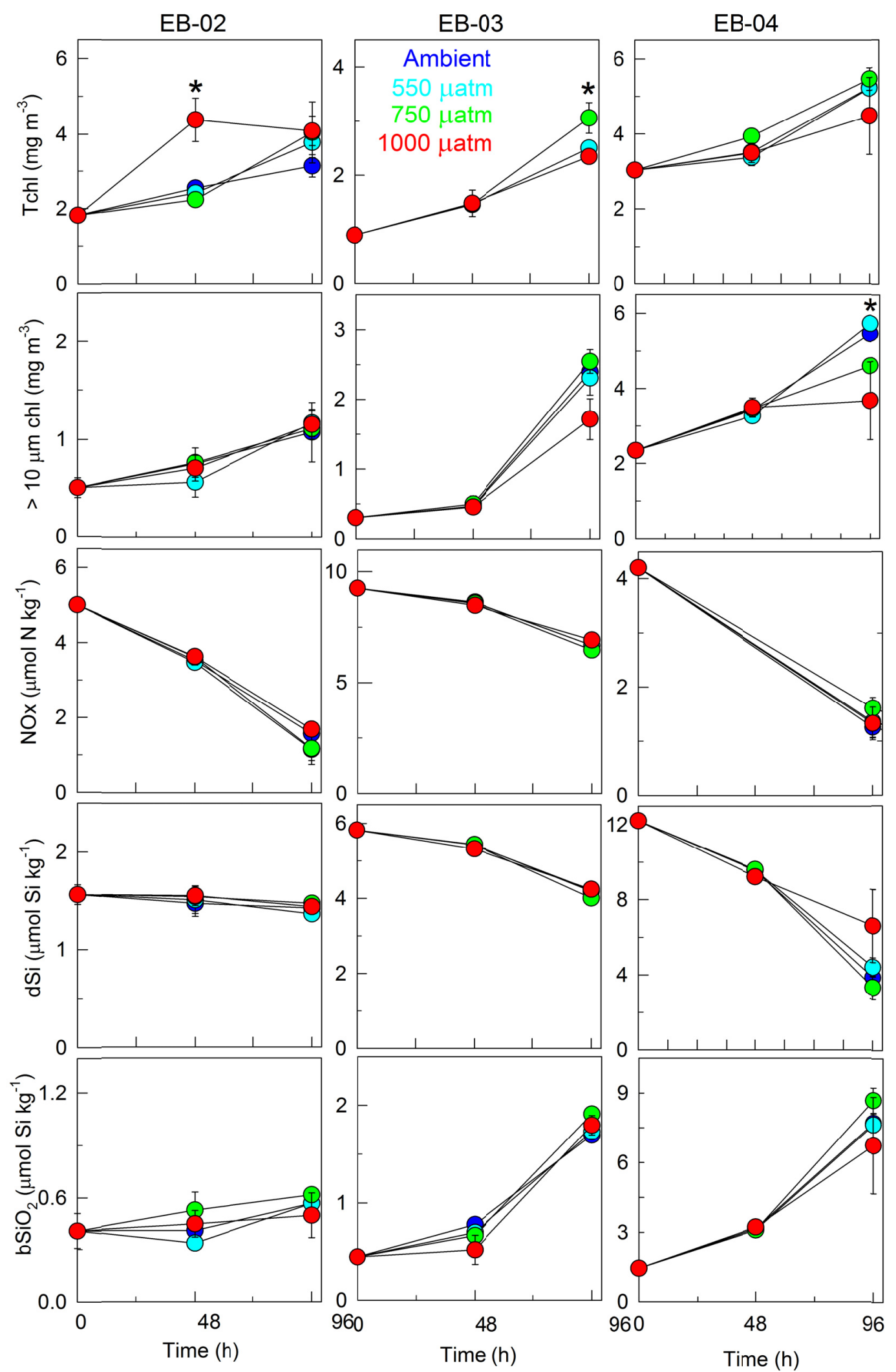
Figure 5

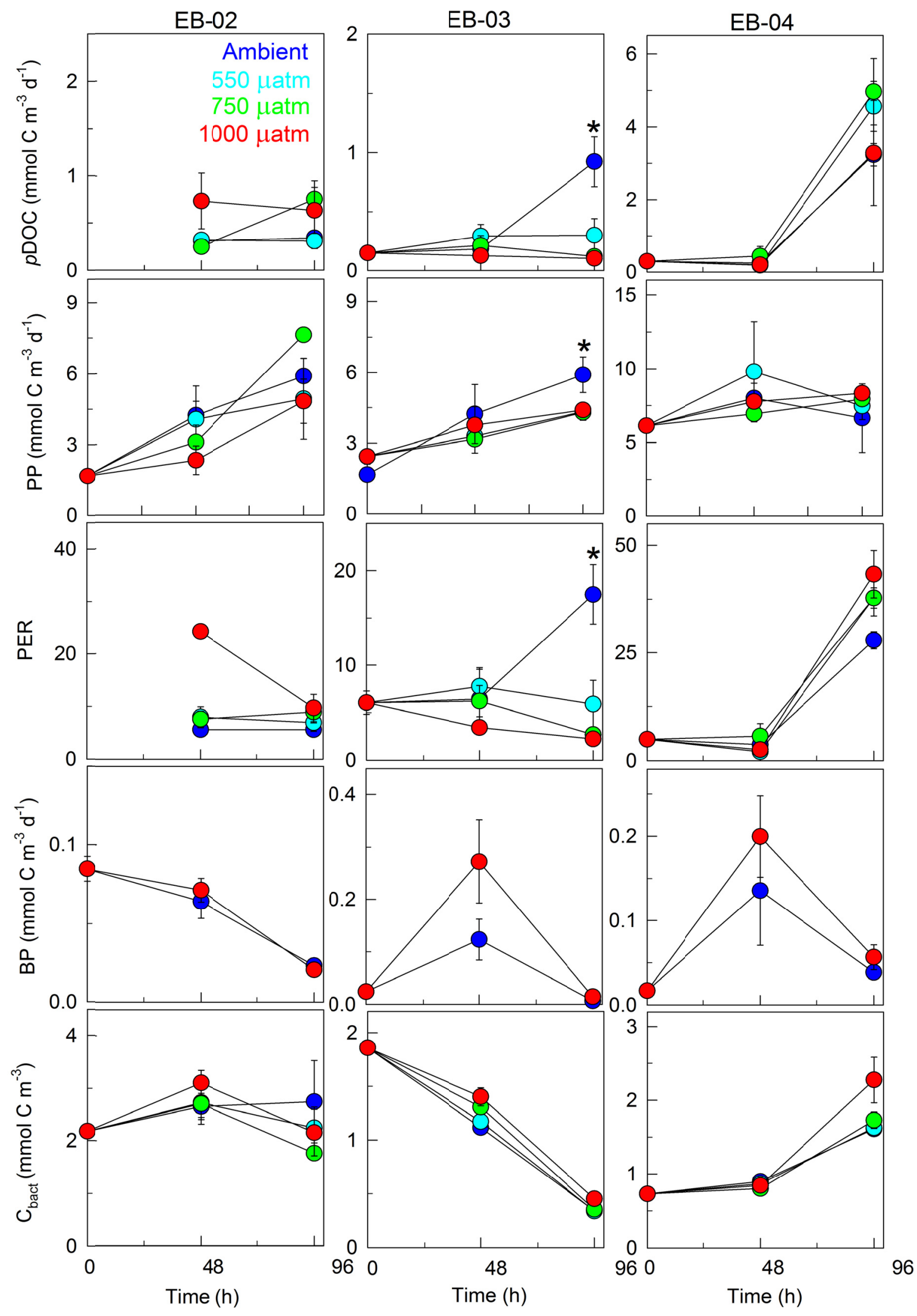


Figure 6
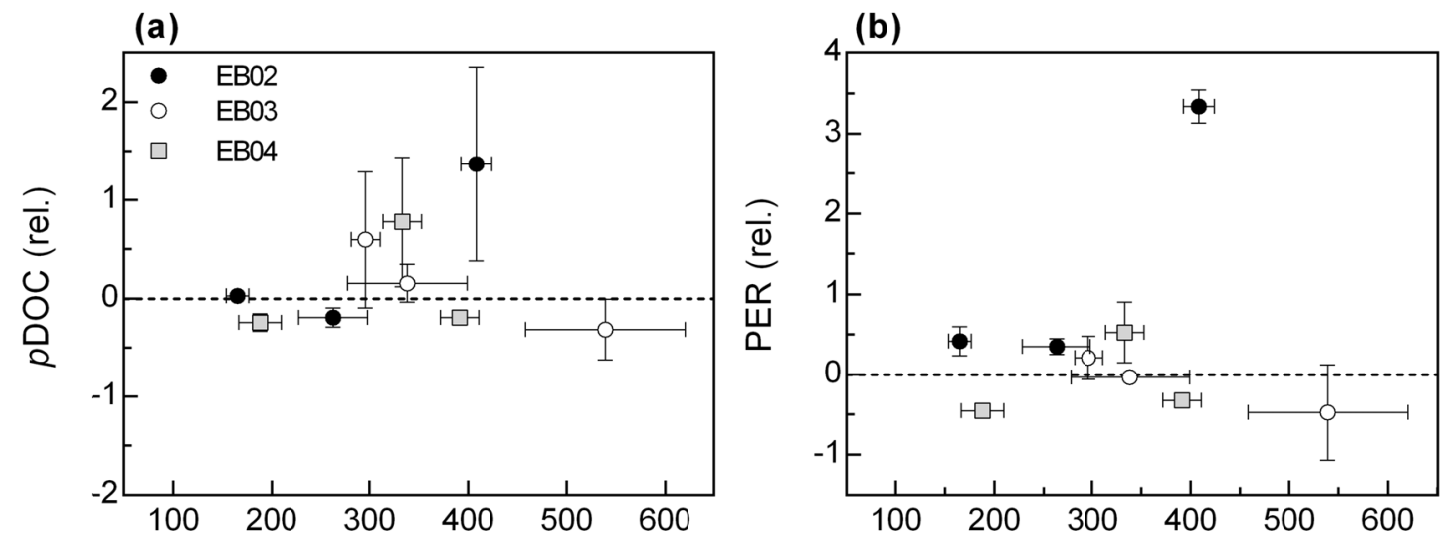

(c)
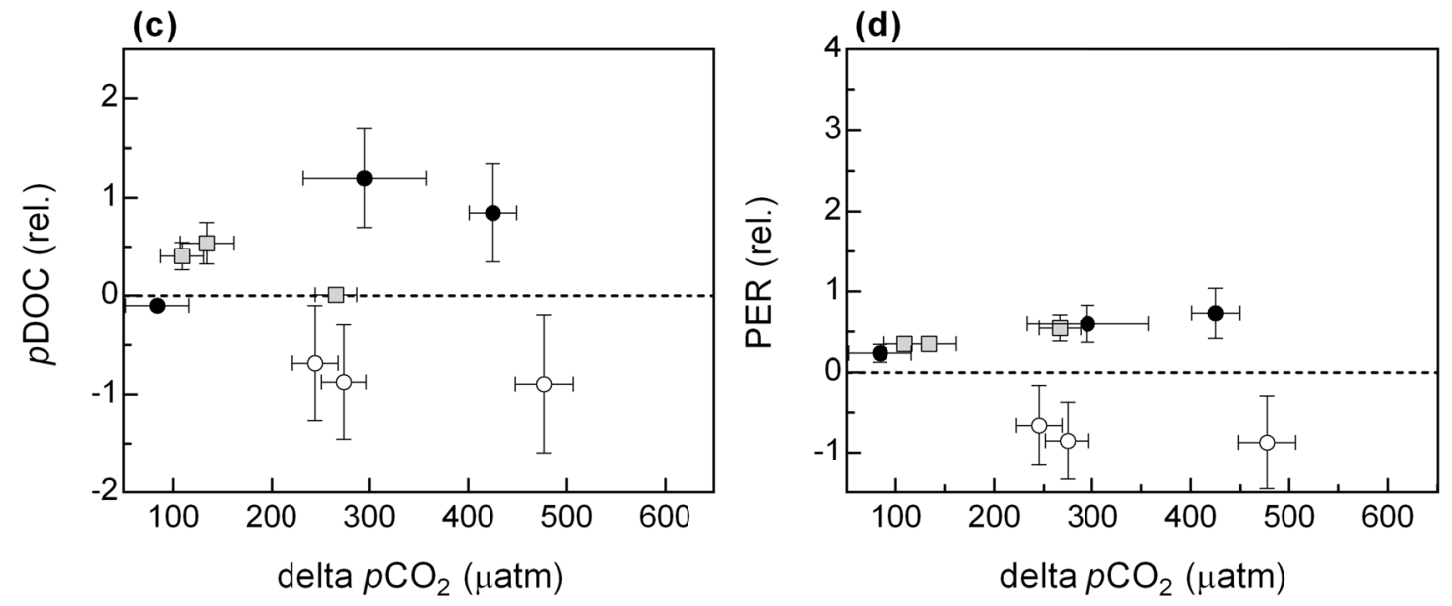
Figure 7

(a)

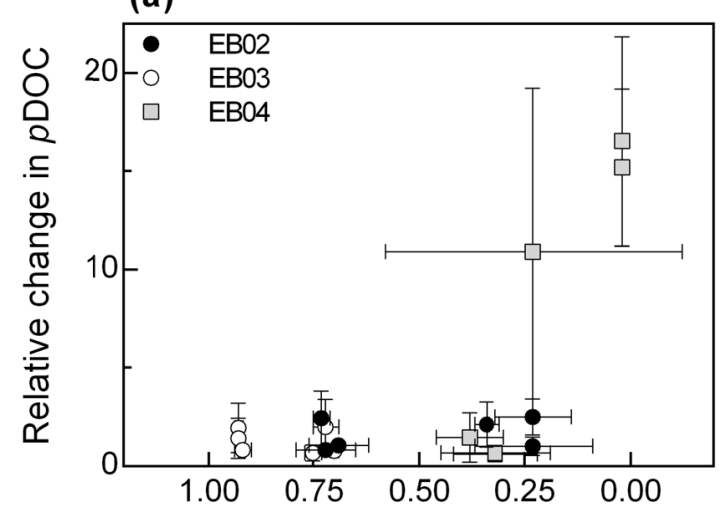

(c)

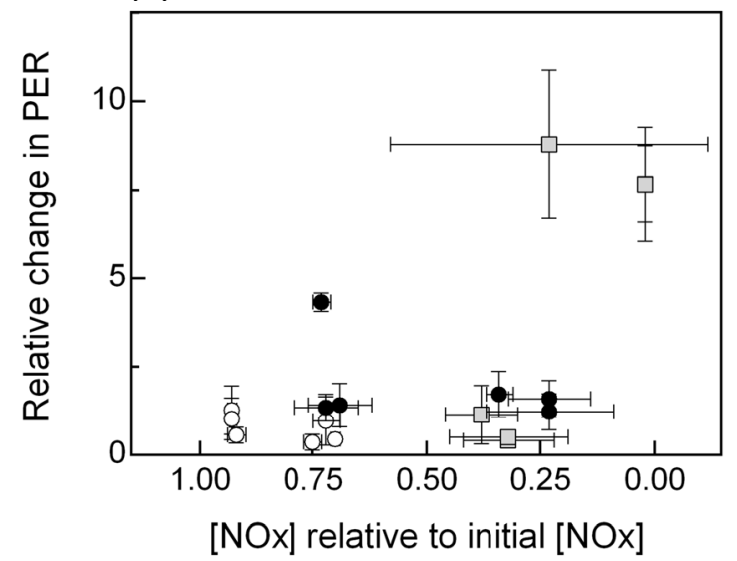

(b)

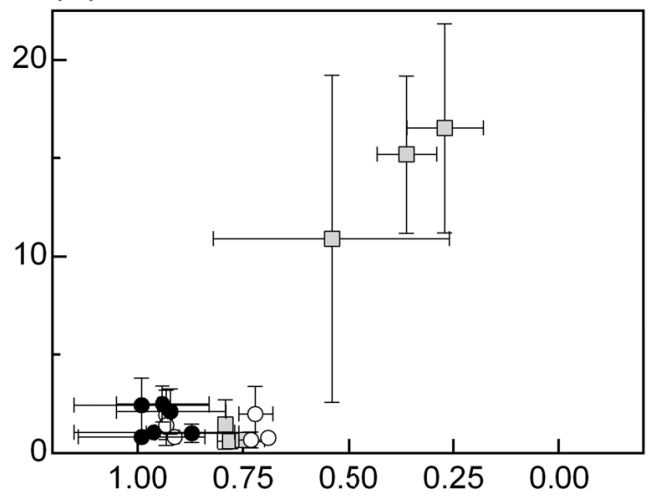

(d)

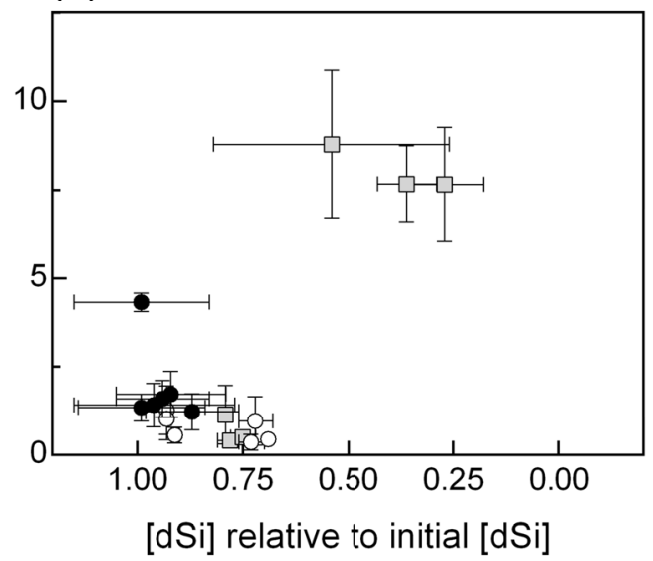

